University of Massachusetts Amherst

ScholarWorks@UMass Amherst

2020

\title{
Sources of inflation and the effects of balanced budgets and inflation targeting in developing economies
}

\author{
Guilherme Klein Martins \\ University of Massachusetts Amherst \\ Peter Skott \\ University of Massachusetts - Amherst
}

Follow this and additional works at: https://scholarworks.umass.edu/econ_workingpaper

Part of the Economics Commons

\section{Recommended Citation \\ Martins, Guilherme Klein and Skott, Peter, "Sources of inflation and the effects of balanced budgets and inflation targeting in developing economies" (2020). UMass Amherst Economics Working Papers. 291. https://doi.org/10.7275/18878435}

This Article is brought to you for free and open access by the Economics at ScholarWorks@UMass Amherst. It has been accepted for inclusion in Economics Department Working Paper Series by an authorized administrator of ScholarWorks@UMass Amherst. For more information, please contact scholarworks@library.umass.edu. 


\title{
Sources of inflation and the effects of balanced budgets and inflation targeting in developing economies*
}

\author{
Guilherme Klein Martins ${ }^{\dagger}$ Peter Skott $\ddagger$
}

August 10, 2020

\begin{abstract}
This paper presents a model of inflation in developing economies and makes uses of it to evaluate macroeconomic policy in those countries. We see cross-sectoral interactions between demand and supply side forces as central and show that the standard macroeconomic policy recommendations of inflation targeting and balanced budgets (i) increase volatility by amplifying external shocks and (ii) can lead to premature deindustrialization. The analysis applies to economies with marked underemployment, a central feature of developing and emerging countries. The recent Brazilian experience is used to illustrate the argument.

JEL codes: E63, O23, O14

Key words: inflation targeting, Dutch disease, overvaluation, commodities boom, Washington consensus
\end{abstract}

\section{Introduction}

Why do economies with large amounts of hidden unemployment and underemployment experience inflationary pressures? Standard economic theory relates inflation to deviations of the actual unemployment rate from its 'natural rate'. But the notion that labor constraints and deviations from a natural rate of unemployment generate inflation and limit economic growth in developing countries would seem hard to defend.

Our analysis of inflation in dual economies has strong affinities with the Latin American structuralist tradition. We see inflation as deriving from social

${ }^{*}$ This work was supported by the Chair's Summer Research Fund from the Department of Economics, University of Massachusetts, Amherst (UMASS). We would like to thank Andre Roncaglia, Jose Luis Oreiro, Gustavo Pereira Serra, and Arslan Razmi as well as the participants of the Umass-NSSR and the Analytical Political Economy (UMASS) workshops. The usual caveats apply.

†Department of Economics, University of Massachusetts, Amherst, gmartins@umass.edu

$\ddagger$ Department of Economics, University of Massachusetts Amherst; pskott@econs.umass.edu 
conflict, inertia related to formal and informal indexation, and sectoral interactions between demand and supply side forces. ${ }^{1}$ Incomes in the informal sector are demand determined, shocks to aggregate demand influence relative incomes, and shifts in relative incomes influence wage setting in the formal sectors of the economy.

Relative wages have a strong normative element, and wage pressures develop in the formal sectors as workers react to shocks and try to preserve 'fair' relative wages. Wage inflation in the formal sectors does not, however, restore the previous relative wages: nominal wage gains in the formal sectors raise incomes in the informal sector pari passu, maintaining the relative incomes that were at odds with prevailing social norms. Thus, in the absence of policy intervention inflationary expectations may build up and lead to explosive inflation. Inflationtargeting monetary policy can keep inflation at a desirable rate, but at the expense of exchange rate appreciation and a shift in economic activities towards nontradable sectors.

Wage norms and informal indexation are central to this process, but social norms evolve endogenously, and this path dependency allows structural transformation and economic development. The gradual elimination of wage premia in the formal sector and underemployment in the informal sector need not provoke high inflation. Large shocks to relative incomes, by contrast, can be inflationary, and if our argument is correct, the standard prescriptions for macroeconomic policy are misguided.

The period from the early 1980s to the turn of the century saw the gradual establishment of a hegemonic macroeconomic agenda of balanced government budgets, inflation targeting and liberalized goods and capital markets. In the European Union the prescriptions are enshrined in the Stability and Growth Pact for fiscal policy and the explicit specification of the primary objective of the ECB as maintaining price stability. ${ }^{2}$ But even when not part of an official set of guidelines and objectives, these principles have guided policy in many countries over the last 20-40 years, developed as well as developing. The most recent OECD Survey on Brazil, for instance, is quite explicit. Following an assessment of the current state of the economy, the survey outlines its main messages. The first of these states that: "[s]tabilising public debt and ensuring that inflation remains close to the target are key macroeconomic priorities" (OECD (2018), p.12). The recommendations, repeated in widely distinct circumstances, have

\footnotetext{
${ }^{1}$ We use the term 'dual economies' to denote economies with pronounced differences between modern sectors and low-productivity informal sectors with significant amounts of underemployment. Economies without significant sectoral differences of this kind are 'mature'.

${ }^{2}$ The Stability and Growth Pact and its various updates are described on the European Commission website, https://ec.europa.eu/info/business-economy-euro/economic-and-fiscalpolicy-coordination/eu-economic-governance-monitoring-prevention-correction/stability-andgrowth-pact_enis . The objectives of the ECB's monetary policy are set out on the bank's website:

"The primary objective of the ECB's monetary policy is to maintain price stability. This is the best contribution monetary policy can make to economic growth and job creation." https://www.ecb.europa.eu/mopo/intro/html/index.en.html
} 
been echoed by national economic institutions and increasingly influence policy making. ${ }^{3}$

Inflation targeting is often described as successful, despite challenges of implementation in emerging and developing economies. ${ }^{4}$ Even when combined with balanced budgets, however, inflation targeting has often failed to deliver the anticipated improvements in real economic performance; Brito and Bystedt (2010), for instance, find evidence that inflation targeting decreased output growth in emerging economies and did not reduce inflation and output volatility. This is no accident, we argue. A combination of balanced budgets and inflation targeting can amplify fluctuations and lead to slow economic growth and premature deindustrialization. ${ }^{5}$

The commodity boom of the early 2000s exemplifies the dangers of the policy mix. Rising commodity prices relaxed both government-budget and balance-ofpayments constraints for many middle-income countries and allowed an expansion of aggregate demand. Incipient inflationary pressures were addressed using monetary policy, and the resulting appreciation of the exchange rate carried additional short-term political benefits by increasing people's real purchasing power. ${ }^{6}$ The negative effects of the policy showed up later. An overvalued exchange rate contributed to deindustrialization and a large expansion of the nontradable sector. When the boom came to end, exchange rates depreciated, inflation increased, and the economies went into recession with a less developed productive structure. The macroeconomic policy prescriptions had contributed to a classical Dutch disease.

The experiences of many Latin American countries fit this pattern. The commodity boom boosted their economies both directly and indirectly via increased fiscal capacity (converted into higher public sector employment, cash transfers and public investment) (IMF (2018)). ${ }^{7}$ The expansion was particularly strong

${ }^{3}$ The same recommendation to Brazilian policy makers had been made 13 years earlier:

"Of particular importance in the macro area are the inflation targeting framework for monetary policymaking and the Fiscal Responsibility legislation" (OECD (2005), p.13).

${ }^{4}$ According to Fraga, Goldfajn, and Minella (2003) (p. 2),

"The performance of inflation targeting regimes around the world has been positive. Average inflation in both emerging markets and developing economies has come down after the adoption of the inflation targeting regime. However, emerging market economies (EMEs) have had a relatively worse preformance. (...) inflation targeting in these countries is a more challenging task than in developed ones."

${ }^{5}$ Rodrik (2016) applies the concept of premature industrialization to countries whose manufacturing sector has declined at income levels much lower than those at which developed countries began to deindustrialize - that is, the economies become specialized in (low-skill) services before having undergone a profound experience of industrialization.

${ }^{6}$ In developing economies interest rates often influence inflation primarily through their effects on the exchange rate. The Brazilian (1994-1999), Argentine (1991-2002) and Mexican (1989-1994) price stabilization programs are illustrative (although extreme) cases of the use of exchange rates to stop inflation.

${ }^{7}$ These developments were pronounced in Ecuador, Bolivia, Argentina, Peru, Brazil, 
in the natural resource and nontradable sectors, notably commerce and construction, while the manufacturing sector shrank from $16.4 \%$ in 2003 to $13.3 \%$ in 2012. ${ }^{8}$ The Brazilian case, which is described in greater detail in section 3, illustrates our argument. The region is not unique, however, and the analytical framework in this paper has, we believe, wider applicability. Many developing economies outside Latin America also have a high dependence on primary commodity exports - 102 countries were in this condition in the period 2013-2017 (UNCTAD (2019) $)^{9}$; Ghana, for instance, followed policies of sound finance and inflation targeting and experienced a similar process of deindustrialization.

We do not suggest that the problems associated with overvalued exchange rates have gone unrecognized. ${ }^{10}$ Many economists have warned of its dangers, and the recognition is not confined to academics. What became known as the 'Washington consensus' (Williamson (1990)) included competitive exchange rates as one of its ten policy prescriptions, although in a later discussion, Williamson (2004) suggested that already by 1990, the consensus had shifted away from seeing competitive exchange rates as a priority. ${ }^{11}$ IMF studies, including Savastano, Masson, and Sharma (1997), have also pointed to potential conflicts in developing countries between inflation targeting and a concern for external competitiveness. The authors note that none of the standard models of inflation "commands support comparable to that obtained by natural rate models in industrial countries" (p. 31-32), and this and other problems make them question "the adoption of a framework akin to IT" in developing countries in the near term (p. 38). But despite these warnings and notes of caution, inflation targeting has been increasingly adopted, also by developing economies, and exchange rate concerns have been largely ignored.

The fiscal dimension of the standard policy recommendations has also come in for criticisms, many of which our analysis is in line with. Austerity policies often motivated by the alleged dangers of public debt - can do and have done immense damage. European policies after the 2008 financial crisis is a case in point, and fiscal consolidation in commodity exporters hurt the economies when the boom came to an end and recession was already approaching. A focus on balanced budgets effectively promotes a procyclical policy and exacerbates macroeconomic instability with detrimental effects on long-term growth.

But stabilization is different from sustained fiscal stimulus. Some developed

Colombia and Paraguay.

${ }^{8}$ Latin America and Caribbean. World Bank data, available at: https://data.worldbank.org/indicator/NV.IND.MANF.ZS

${ }^{9}$ Mainly in Africa, Middle East, and East Asia (UNCTAD (2017))

${ }^{10}$ E.g. Krugman (1987), Ros and Skott (1998), Gala (2007) Rodrik (2008) and Razmi, Rapetti, and Skott (2012).

${ }^{11}$ Williamson (2004) (p. 3):

I fear I indulged in wishful thinking in asserting that there was a consensus in favor of ensuring that the exchange rate would be competitive, which essentially implies an intermediate regime; in fact, Washington was already beginning to edge towards the two corner doctrine, which holds that a country must either fix firmly or else it must float 'cleanly'. 
economies have faced severe structural aggregate demand problems (Japan is a clear example), and a balanced budgets and inflation targeting policy impart a long term deflationary bias without full employment in those countries. Developing economies, however, do not have structural aggregate demand problems, and expansionary aggregate demand policy is not a development strategy. Abandoning balanced budgets in favor of more aggressive sustained fiscal expansion while complying with rigid monetary policies can aggravate the damage and push these developing economies further in the direction of deindustrialization. ${ }^{12}$

To summarize, in this paper we present a model of inflation in dual economies. Sectoral specificities and interactions between demand and supply side forces are at the core of the model. If the inflation analysis is correct, second, we show that a policy combination of balanced budgets and inflation targeting may derail economic development.

A brief comment on methodology is relevant, we belive. Formal models can help structure and clarify ideas and inform empirical studies. To be useful they must simplify, and the model in this paper is no exception. Our modeling approach, however, may be unfashionable: the absence of intertemporally optimizing representative agents may seem like a glaring deficiency. We make no apologies for this. In our judgment the simplifications we have chosen provide a much better starting point than DSGE models with intertemporal optimization, rational expectations and fluctuations around a steady growth path with a natural rate of unemployment - a framework that is particularly problematic when applied to economies with pronounced sectoral differences and a need for structural transformation. ${ }^{13}$

The rest of the paper is structured in four sections. Section 2 uses a foursector model of a dual economy model with conflict-driven inflation to examine some implications of balanced budgets and inflation targeting policies. The Brazilian case is outlined in Section 3 which also includes a discussion of differences and similarities between our account and other inflation theories and interpretations of Brazil's experience. Section 4 offers a few concluding comments and observations.

\section{The model}

\subsection{Overview}

The model includes four sectors: a commodity sector producing a pure export good, two formal sectors, one producing a tradable and one producing a nontradable good, and an informal sector producing a nontradable good.

\footnotetext{
${ }^{12} \mathrm{~A}$ vast literature considers possible relations between industrialization, technological change and economic development; see, e.g. Rodrik (2013), Haraguchi, Cheng, and Smeets (2017) and Dosi and Nelson (2010).

${ }^{13}$ Our approach differs from some other alternatives to DSGE models, such as agent-based models. We see our 'classical' approach and agent-based models as potentially complementary; one virtue of our analytical strategy, we believe, is the clarity of causal mechanisms.
} 
We use the term informal as a short-hand for activities with substantial underemployment and low incomes. Most of these activities are informal in a legal sense, but it is not the legal status, 'formality' per se, that is important; the registration of street vendors would not change the reality of their situation. The informal sector in middle income countries typically includes a myriad of precarious urban activities, many of them in services. The sector is large in those countries and has much lower productivity and average incomes than formal sectors; summarizing 'five facts about informality', La Porta and Shleifer (2014) find the evidence to be broadly consistent with the dual view of informality associated with Lewis and classical development theory.

The output of the informal sector is nontradable, but a sizable part of nontradables, particularly in services and commerce, is produced by a formal sector. The distinction between formal and informal nontradable sectors therefore can be important.

\subsection{Assumptions}

\subsubsection{Production and pricing}

The formal sector is composed of two subsectors, a tradable and a nontradable one. Both sectors use capital and labor. Capital stocks are given in the short run and labor is the only variable input

$$
\begin{aligned}
M & =F^{M}\left(L_{M}\right) \\
S & =F^{S}\left(L_{S}\right)
\end{aligned}
$$

$M$ and $S$ denote the output of tradable and nontradable goods; $L$ is employment with subscripts denoting the sector.

Nominal wages are predetermined in both formal sectors, and the marginal product of labor and the markup are taken as constant in the benchmark version of the model (these assumptions are relaxed in section 2.8). Thus, prices become predetermined too, and changes in demand are met by quantity adjustments. Normalizing labor productivities to one, we have

$$
\begin{aligned}
M & =q_{M} L_{M}=L_{M} \\
S & =q_{S} L_{S}=L_{S}
\end{aligned}
$$

and

$$
\begin{gathered}
p_{M}=\frac{w_{M}}{\left(1-\pi_{M}\right) q_{M}}=\frac{w_{M}}{1-\pi_{M}} \\
p_{S}=\frac{w_{S}}{\left(1-\pi_{S}\right) q_{S}}=\frac{w_{S}}{1-\pi_{S}}
\end{gathered}
$$

where $\pi_{i}$ denotes the profit share in sector $i$.

The resource sector produces a pure export good, which we shall refer to as 'commodities'; the output of this sector may include oil, minerals, or specific agricultural goods. For simplicity it is assumed that no domestic inputs 
are involved in its production. This assumption is clearly extreme, but the qualitative analysis is unaffected as long as export shocks have little effect on the allocation of domestic inputs of labor and capital to this sector. In other words, we are capturing the exogenous rents that characterize these activities. The value of exports in foreign currency $(Z)$ is exogenous.

The informal sector, finally, produces a non-tradable good and uses labor as the only input. Workers that fail to find jobs in the formal sectors move to the informal sector which is characterized by hidden unemployment and underemployment. Thus, if $N$ denotes the total labor force, we have

$$
L_{A}=N-L_{S}-L_{M}=(N-S-M)
$$

The average income in the informal sector is given by

$$
w_{A}=\frac{p_{A} A}{L_{A}}
$$

where $A$ is output in the informal sector and $p_{A}$ its price level.

\subsubsection{Demand}

The two nontradable sectors produce pure consumption goods. The domestically produced tradable good, by contrast, can be used for either investment or consumption. It is assumed that all investment goods are produced domestically; results do not change qualitatively if this assumption is relaxed (see section 2.8). Total investment is the sum of investment in both formal sectors and is determined by their levels of output (corresponding to the utilization rates of capital) and the real rate of interest $(r)$,

$$
I=I(M, S, r)
$$

All wages and informal sector incomes are spent on consumption while only a portion $(1-s)$ of profits is consumed. The revenues from commodities go partly to the government and partly to the private sector. We assume that a portion $\epsilon$ of the revenues is spent on public and private consumption and that the state receives a fixed proportion of the revenues.

Algebraically, nominal private consumption $(C)$ and government consumption $(G)$ are given by:

$$
\begin{aligned}
C & =p_{A} A+\left(1-\pi_{S}\right) p_{S} S+\pi_{S} p_{S} S(1-s)+\left(1-\pi_{M}\right) p_{M} M \\
& +\pi_{M} p_{M} M(1-s)+(1-\beta) \epsilon E Z \\
G & =\beta \epsilon E Z
\end{aligned}
$$

where $E$ is the nominal exchange rate and $\beta$ the share of resource revenues going to the state. For simplicity, we leave out taxation of incomes in the non-resource sectors and assume that government spending is determined by taxes and royalties from the resource sector; a balanced government budget is obtained if $\epsilon=1$ and a fiscal surplus if $\epsilon<1$. Given the purposes of this paper, 
little would be gained by including taxes on wages and profits in the formal sectors. ${ }^{14}$

Private and government consumption are split between four goods: two nontradables (formal and informal) and two tradables (domestically produced and imported). The benchmark version of the model assumes that each of the four goods receives a fixed share of total domestic spending on consumption (corresponding to a Cobb-Douglas utility function); the shares of the $M, S$ and $A$ sectors are $\alpha_{M}, \alpha_{s}, \alpha_{A}$, leaving $\theta=\left(1-\alpha_{M}-\alpha_{S}-\alpha_{A}\right)$ as the share for imports. This demand specification is relaxed in section 2.8 .

Net exports $(N X)$ are equal to the sum of resource exports and net exports of modern sector goods. Nominal imports are given as a share $(\theta)$ of domestic nominal consumption; real exports of the tradable $M$-good $(X)$ are determined by foreign income and the international competitiveness of the domestic tradable sector. The main determinant of competitiveness in the short run is the relative price $p_{M}^{*} E / p_{M}$, and - normalizing the foreign currency price of imported goods to one $\left(p_{M}^{*}=1\right)$ and omitting foreign income as an explicit argument - we have that

$$
\begin{aligned}
N X & =p_{M} X-E p_{M}^{*} I M+E Z \\
& =p_{M} X(\eta)-\theta(C+G)+p_{M} \eta Z ; \quad X^{\prime}>0
\end{aligned}
$$

where

$$
\eta=\frac{E p_{M}^{*}}{p_{M}}=\frac{E}{p_{M}}
$$

With a slight abuse of terminology, we shall refer to $\eta$ as the real exchange rate.

\subsection{Short run equilibrium}

We have the following equilibrium conditions for the $M, S$ and $A$ sectors: $^{15}$

$$
\begin{aligned}
p_{M} M= & \alpha_{M}(C+G)+p_{M} I+p_{M} X \\
& p_{S} S=\alpha_{S}(C+G) \\
& p_{A} A=\alpha_{A}(C+G)
\end{aligned}
$$

Using (8)-(9) and (11)-(13) aggregate domestic consumption - private and government - can be written

$$
C+G=\frac{p_{M}\left[\left(1-\pi_{M} s\right)(I+X)+\eta Z \epsilon\right]}{\theta+s\left(\alpha_{M} \pi_{M}+\alpha_{S} \pi_{S}\right)}
$$

\footnotetext{
${ }^{14}$ Skott (2020) considers fiscal policy in more detail.

${ }^{15}$ The investment and export variables $(I$ and $X)$ are in real terms. With multiple consumption goods, however, private and public consumption $(C+G)$ are defined in nominal terms.
} 
From equations (11)-(12) and (14) it follows that

$$
\begin{aligned}
& M=\alpha_{M} \frac{\left(1-\pi_{M} s\right)[I(M, S, r)+X(\eta)]+\eta Z \epsilon}{\theta+s\left(\alpha_{M} \pi_{M}+\alpha_{S} \pi_{S}\right)}+I(M, S, r)+X(\eta) \\
& S=\alpha_{S} \frac{p_{M}}{p_{S}} \frac{\left(1-\pi_{M} s\right)[I(M, S, r)+X(\eta)]+\eta Z \epsilon}{\theta+s\left(\alpha_{M} \pi_{M}+\alpha_{S} \pi_{S}\right)}
\end{aligned}
$$

The short run solution defined by equations (15)-(16) is economically meaningful if the Keynesian stability conditions are satisfied. The standard intuition still applies for this two-sector system: stability requires investment to be relatively insensitive to variations in output, now taking into account the interactions between the two sectors (see Appendix A for details).

As shown in Appendix B, if $M^{*}$ and $S^{*}$ denote the short run equilibrium solutions, we have

$$
\begin{array}{lll}
\frac{\partial M^{*}}{\partial Z}>0 ; & \frac{\partial S^{*}}{\partial Z}>0 \\
\frac{\partial M^{*}}{\partial \eta}>0 ; & \frac{\partial S^{*}}{\partial \eta}>0 \\
\frac{\partial M^{*}}{\partial r}<0 ; & \frac{\partial S^{*}}{\partial r}<0
\end{array}
$$

Intuitively, an increase in commodity revenues stimulates consumption and raises capacity utilization of both sectors. The benchmark specification of demand ensures that a depreciation (a rise in $\eta$ ) would boost demand in the tradable sector, with positive derived effects for nontradables. Analogously, an increase in interest rates would have its direct effect (in this case negative) on investment and the demand for tradables, with derived effects for nontradables.

Aggregate income in the informal sector can be determined by (13)-(14) or alternatively, using (12)-(13), by noting that

$$
p_{A} A=\frac{\alpha_{A}}{\alpha_{S}} p_{S} S
$$

The effects of a commodity boom on net exports are ambiguous without restrictions on the various parameters. We have,

$$
\frac{\partial N X}{\partial Z} \gtreqless 0, \quad \frac{\partial N X}{\partial \eta} \gtreqless 0, \quad \frac{\partial N X}{\partial r}>0
$$

A shock to commodity revenues has a direct impact on domestic consumption with derived effects on investment, domestic saving and imports. The effect on net exports can become negative if the consumption rate out of the commodity revenue is high ( $\epsilon$ is large), the import propensity out of consumption is large ( $\theta$ is large) and the sensitivity of accumulation to changes in output is sufficiently high (see Appendix B). The derived effects on imports may also dominate the positive effects of a depreciation on total exports (on $X(\eta)+\eta Z$ ), and the effects of a depreciation on the trade balance are ambiguous. 


\subsection{Wage setting and inflation}

The levels of money wages in the formal sectors are predetermined in the short run. But the average income in the informal sector is endogenous, and the rates of wage inflation in the formal sectors cannot be taken as constant.

Combining equations (5)-(6) and (16)-(17), the average income in the informal sector is given by

$$
\begin{aligned}
w_{A} & =\frac{p_{A} A}{N-L_{M}-L_{S}}=\frac{\alpha_{A}(C+G)}{N-L_{M}-L_{S}} \\
& =\frac{\alpha_{A}}{N-M-S} \frac{p_{M}\left[\left(1-\pi_{M} s\right)(I+X)+\eta Z \epsilon\right]}{\theta+s\left(\alpha_{M} \pi_{M}+\alpha_{S} \pi_{S}\right)}
\end{aligned}
$$

Changes in informal sector incomes need not affect the prices of informal goods: a rise in demand for informal goods can raise the price $p_{A}$, or it can reduce the rate of underemployment and raise the level of output $A$; of course, it can also be some combination of the two. Given the Cobb-Douglas specification of the composition of consumption demand, however, the effects on average incomes in the informal sector are independent of changes in $p_{A}$. Thus, even if prices of informal goods stay constant, an increase in informal-sector incomes has repercussions for wage inflation in the formal sectors if workers in these sectors react by pushing to increase their income.

The notion that norms of fairness influence wage setting has a long history in economics. Keynes (1936) famously explained wage stickiness by workers' resistance to wage cuts that could reduce their relative wages, and Akerlof and Yellen (1990) pointed to wage norms as the source of unemployment among lowwage workers. Experimental and real-world evidence confirms the significance of notions of fairness for wage and price setting (e.g. Kahneman, Knetsch, and Thaler (1986), Bewley (1998)).

Our benchmark specification of wage inflation in the formal sector embodies relative-wage norms: increases in informal-sector incomes generate cost-push pressures on wages in the formal sector. Formally, we assume that

$$
\begin{aligned}
& \hat{w}_{M}=\phi_{M}\left(\frac{w_{M}^{f}}{w_{M}}\right)+\hat{p}^{e} ; \quad \phi_{M}(1)=0, \phi_{M}^{\prime}>0 \\
& \hat{w}_{S}=\phi_{S}\left(\frac{w_{S}^{f}}{w_{S}}\right)+\hat{p}^{e} ; \quad \phi_{S}(1)=0, \phi_{S}^{\prime}>0
\end{aligned}
$$

where $\hat{p}^{e}$ is the expected inflation rate. The 'fair wages' $w_{M}^{f}$ and $w_{S}^{f}$ are determined by the average incomes and wages in other sectors, that is

$$
\begin{gathered}
w_{M}^{f}=f^{M}\left(w_{A}, w_{S}\right) \\
w_{S}^{f}=f^{S}\left(w_{A}, w_{M}\right)
\end{gathered}
$$

With a fixed markup, wage inflation maps directly into price inflation. Successful inflation targeting therefore requires that actual wages equal fair wages; 
that is, the following conditions must be met:

$$
\begin{gathered}
w_{M}=w_{M}^{f}=f^{M}\left(w_{A}, w_{S}\right) \\
w_{S}=w_{S}^{f}=f^{S}\left(w_{A}, w_{M}\right)
\end{gathered}
$$

We assume that the fair wages in the formal sectors exceed average incomes in the informal sector. A non-negative wage premium is in line with the classical assumption of elastic labor supply to the modern sectors in Lewis (1954), and a strictly positive wage premium has empirical and theoretical support. Firms willingly pay a wage premium because it increases productivity: as in Akerlof and Yellen (1990) and other efficiency wages models, a perception of unfair wages can generate adverse effects on productivity via collective action, including strikes, or by hurting 'morale' and reducing the 'effort' of individual workers. ${ }^{16}$

\subsection{Inflation targeting with constant fairness norms}

Given the specification of wage setting, a positive shock to $w_{A}$ generates inflationary pressures in the formal sectors. For given values of the predetermined wage levels $w_{M}$ and $w_{S}$, wage inflation is a strictly increasing function of $w_{A}$,

$$
\begin{aligned}
\frac{\partial \hat{w}_{M}}{\partial w_{A}} & >0 \\
\frac{\partial \hat{w}_{S}}{\partial w_{A}} & >0
\end{aligned}
$$

There are asymmetries between the two sectors, however.

Consider first the effects of wage inflation in the non-tradable sector. If wages and prices in the tradable sector stay constant, an increase in the prices of nontradable goods will not ignite a process of continuing inflation. Nominal spending on private and public consumption is independent of the price level in the nontradable sectors (equation (14)). An increase in the prices of nontradable goods therefore has no direct effect on total informal-sector incomes. However, it reduces real output and employment in $S$, sending workers into the informal sector and reducing the average income in this sector. The contraction in $S$ also has derived negative effects on investment, causing employment in the tradable sector to fall, leading to a further decline in aggregate informal sector income. Adjustments in $w_{S} / w_{A}$ in response to a shock to $w_{A}$ therefore tend to be selfcorrecting; if an increase in $w_{A}$ produces a rise in $w_{S}$, the induced decline in $w_{A}$ ensures that $w_{S} / w_{A}$ will go up, moving towards a restoration of the previous relative wage.

An increase in tradable wages and prices, by contrast, raises the nominal demand for non-tradable goods (equation (14)). If investment and the exports

\footnotetext{
${ }^{16}$ Efficiency wage arguments for a wage premium in the formal sector can also be nutritionbased (Leibenstein (1957)) or use a traditional utility-based approach to the determination of 'effort' (e.g. Shapiro and Stiglitz (1984), Bowles (1985)).
} 
of commodities and $M$ goods stay constant, an increase in $w_{M}$ produces a proportional rise in the average nominal income in the informal sector and leaves the 'relative wage' $w_{M} / w_{A}$ unchanged. Nominal incomes in the $S$-sector, which, as total informal sector income, are determined by $C+G$, also increase proportionately, generating some combination of increases in $w_{S}$ and $L_{S} \cdot{ }^{17}$ As a result of these interactions between an initial rise in $w_{A} / w_{M}$ and the ensuing cost-push adjustments in tradable-sector wages and prices - which feed into new increases in nominal demand for the informal good - the $w_{A} / w_{M}$ ratio does not return to its former value. Instead, we may get a cycle of persistent and potentially (depending on how expectations are formed) explosive inflation.

Intuitively, this asymmetry between tradable and nontradable prices is related to a standard Keynesian multiplier process. Incomes in the tradable, nontradable and resource sectors all generate consumption demand. A constant fraction of consumption demand goes to the nontradable sector, and this feedback creates a multiplier relation: incomes in the nontradable sector are determined by the product of the multiplier and the 'outside demand' from the tradable and resource sectors; this outside nominal demand is influenced by $p_{M}$.

The two sectors differ in another way, too. The absence of foreign competition in the nontradable sector is likely to make firms less reluctant to grant wage increases, and we would expect to see faster adjustment speeds in the nontradable formal sector than in the tradable one. ${ }^{18}$ As a stylized version of this difference, we consider the case in which $\phi_{S}^{\prime} \rightarrow \infty$.

Assume a situation in which $w_{S}$ is less than its 'fair' value. As argued above, an increase in $w_{S}$ will raise $w_{S} / w_{A}$. If $w_{M}$ is predetermined (adjusts slowly), $w_{S} / w_{M}$ will also increase, and, with fast $w_{S}$ adjustment, will converge to $w_{S}^{f}$. Formally, we have

$$
w_{S}=f^{S}\left(w_{A}, w_{M}\right)=w_{M} f^{S}\left(\frac{w_{A}}{w_{M}}, 1\right)
$$

or

$$
\frac{w_{S}}{w_{M}}=f^{S}\left(\frac{w_{A}}{w_{M}}, 1\right)=\zeta\left(\frac{w_{A}}{w_{M}}\right) ; \quad \zeta^{\prime}>0
$$

Using equations (19), (21) and (25) and assuming that the central bank has succeeded in establishing the credibility of the inflation target $\left(\hat{p}^{e}=\hat{p}^{T}\right)$, the condition for $\hat{w}_{M}=\hat{w}_{S}=\hat{p}^{T}$ can now be written

$$
f^{M}\left(\frac{w_{A}}{w_{M}}, \zeta\left(\frac{w_{A}}{w_{M}}\right)\right)=1
$$

The function on the left hand side is increasing in $w_{A} / w_{M}$, and the equation

\footnotetext{
${ }^{17}$ A proportional increase in $w_{S}$ leaves $L_{S}$ unchanged but implies that the ratio of fair to actual wages in the $M$-sector is unaffected by changes in $w_{M}$; a less than proportional increase in $w_{S}$ implies a rise in $L_{S}$, which reduces employment in the informal sector, and the average income of informal workers now rises more than proportionately to changes in $w_{M}$.

${ }^{18}$ The tradable sector may increase wages but be forced by foreign competition to absorb some of the increase via reduced profit margins. We consider induced changes in profit margins in section 2.8 .
} 
defines a unique solution for the wage ratio,

$$
\frac{w_{A}}{w_{M}}=\mu
$$

Combining equations (3), (18) and (27), we have

$$
\mu=\frac{\alpha_{A}}{N-M-S} \frac{\frac{1-\pi_{M} s}{1-\pi_{M}}(I+X)+\frac{\eta Z \epsilon}{1-\pi_{M}}}{\theta+s\left(\alpha_{M} \pi_{M}+\alpha_{S} \pi_{S}\right)}
$$

Central banks cannot control inflation perfectly and instantaneously, even at the best of times. But because of the interactions between wages in the tradable sector and incomes in the informal sector, it becomes imperative to stamp out price acceleration in the tradable sector; conversely, there will be no explosive inflationary cycle, and inflation targeting can be successful as long as central banks keep wage inflation in the tradable sector at the target rate. ${ }^{19}$ Thus, if wage norms are constant, successful inflation targeting implies that, on average, equation (28) will be satisfied in the medium run, at least approximately.

Ignoring short run deviations, consider the implications of a 'perfect' policy regime under which equation (28) holds at all times. Inflation targeting works in this model because monetary policy influences the demand for the tradable sector and thereby the relative wage and the inflation rate: there is a direct influence of interest rates on investment (equation (7)) and an appreciation caused by a rise in the domestic interest rate affects exports (equation (11)).

Standard interest parity arguments suggest the determination of the nominal exchange rate $E$ by domestic interest rates, foreign interest rates, the expected future exchange rate, and risk considerations. Thus, let

$$
E=E\left(i, i^{*}, E^{e}, \tau\right)
$$

where $i$ and $i^{*}$ are domestic and foreign nominal interest rates; $i=r+\hat{p}^{e}$. The expected exchange rate $E^{e}$ and the country risk $\tau$ may change in response to resource booms and other exogenous shocks, whether domestic or international. Subsuming these factors and the exogenous or predetermined values of $i^{*}, p_{M}^{*} / p_{M}, \hat{p}^{e}$ in the shift variable $\rho$, we assume that the real exchange rate is given by

$$
\eta=\frac{p_{M}^{*} E\left(r+\hat{p}^{e}, i^{*}, E^{e}, \tau\right)}{p_{M}}=\eta(r ; \rho) ; \quad \eta_{r}<0
$$

\subsection{Commodity booms, inflation targeting and the Dutch disease}

Inflation targeting endogenizes the interest rate, and equations (28) and (30) in combination with (15)-(16) determine the levels of output in the two formal

\footnotetext{
${ }^{19} \mathrm{~A}$ focus on the derived inflationary effects of shocks is in line with the 'consensus view':

the professional consensus among academic and central bankers is that a central bank should accommodate the direct price-level impact of the shock while calibrating monetary policy so as to avoid further rounds of price increases. (Fraga et al. 2003, p. 32)
} 
sectors, the real interest rate $r$ and the real exchange rate $\eta$. The comparative statics now become quite different from those in section 2.3.

Policy makers still follow principles of sound finance and maintain a nonnegative government balance; that is, we assume that $\epsilon \leq 1$ stays constant. But a commodity boom feeds consumption demand, and contractionary monetary policy is needed to keep inflation at the target level. If $r$ and $\eta$ were to remain constant, an increase in $Z$ would raise $M$ and $S$ (section 2.3 and Appendix B), and $G+G$ would also increase. The average income in the informal sector would go up and inflation would increase.

To prevent the increase in inflation, central banks raise the interest rate $r$ which causes the exchange rate to appreciate ( $\eta$ falls). The policy response leads to a decline in $M, S$ and $C+G$ (section 2.3, Appendix B and (14)); the rise in $w_{A}$ is curtailed and the increase in the interest rate offsets the inflationary effects of the commodity boom and keeps inflation at the target rate.

In this policy regime, a commodity boom produces a contraction in the tradable sector while nontradables expand. Formally, we have (see Appendix C for details)

$$
\frac{\partial M}{\partial Z}<0 ; \quad \frac{\partial S}{\partial Z}>0
$$

Intuitively, interest rates have to be raised in order to avoid a violation of the prevailing relative-wage norms and the ensuing inflation. The direct effects of higher interest rates fall on the tradable sector: investment falls and the currency appreciates which reduces exports. ${ }^{20}$ By contrast, the derived effects on the consumption demand for the $S$ and $M$ goods are proportional. The overall effect therefore falls more heavily on the $M$ sector.

The shifts in the composition of formal-sector output away from tradable goods have dynamic effects on the patterns of investment which also shift towards the nontradable sector. The long-term effects of these shifts are beyond the scope of this paper. ${ }^{21}$

\subsection{Money illusion, endogenous norms and path depen- dency}

If the fairness norms were fixed and time-invariant, the analysis in section 2.6 would represent a twist on a common story: high wage demands by 'insiders' (in this case workers in the formal sector) can lead to high natural rates of unemployment.

But social norms are sustained by continuous validation; they change gradually when outcomes differ from expectations. Like the role of norms of fairness

\footnotetext{
${ }^{20}$ The commodity boom may reduce country risk and generate an appreciation of the exchange rate. If the appreciation causes a large reduction in the demand for tradable goods, the interest rate could fall, even though the risk-adjusted rate has increased.

${ }^{21}$ Another possible impediment to long-run growth is related to net exports. As indicated in appendix B, if $X$ and $I$ are not fixed, as is expected outside the short run, the combination of a boost to aggregate demand and exchange rate appreciation tends to cause unsustainable trade deficits and lead to future contractions. Araujo and Lima (2007) analyze implications of balance of payments constrained growth in a multi-sectoral framework.
} 
in wage setting, the recognition of the conventional aspect of norms has a long history, and evidence from social psychology and behavioral economics support the path dependency of social norms. In the words of Kahneman, Knetsch, and Thaler (1986) (p. 730-1), ${ }^{22}$

the reference transaction provides a basis for fairness judgments because it is normal, not because it is just. Psychological studies of adaptation suggest that any stable state of affairs tends to become accepted eventually, at least in the sense that alternatives to it no longer readily come to mind. Terms of exchange that are initially seen as unfair may in time acquire the status of reference transaction.

The conventional nature of norms can lead to hysteresis in both employment and income distribution in a mature economy, and modified versions of the hysteresis argument carry over to developing ones: the long-run growth rate may be affected by macroeconomic policy in dual economies. ${ }^{23}$

Following Kahneman, Knetsch, and Thaler (ibid.) and the behavioral evidence, suppose that the fair wage ratio changes over time in response to differences between actual and fair relative wages, that is, $\mu$ changes in response to differences between $w_{A} / w_{M}$ and $\mu$. Formally, let

$$
\hat{\mu}=\lambda\left(\frac{\omega}{\mu}-1\right)
$$

where $\omega=w_{A} / w_{M} \cdot^{24}$

Now consider a trajectory in which the wage ratio $\omega$ is kept slightly above the fair relative wage (but below one so that the tradable sector can still attract workers). Formally, let $\omega=\mu+a(1-\mu)$ where $a>0$ is small. Using equation $(31)$,

$$
\dot{\mu}=\lambda a(1-\mu)>0
$$

The fair wage ratio $w_{A} / w_{M}$ gradually rises, and the actual ratio rises with it. Putting it differently, the wage premium in the tradable sector is slowly eroded.

Equations (19)-(20) imply that discrepancies between fair and actual wages produce wage inflation above the expected rate (which by assumption equals the

\footnotetext{
${ }^{22}$ Economists had made similar observations before 'behavioral economics'. Hicks (1975) (p. 65), for instance, argued that "no system of wages when it is called into question, will ever be found to be fair. ... [To avoid the system being called into question] the system of wages should be well established, so that it has the sanction of custom. It then becomes what is expected; and (admittedly on a low level of fairness) what is expected is fair" (p. 65).

${ }^{23}$ See Skott (2005) for an analysis of path dependency in mature economies.

${ }^{24}$ The symmetric specification in equation (31) has the virtue of simplicity but misses an important aspect of norm adjustment: fairness norms are likely to adjust quickly in an upward direction (we quickly feel that pay increases are 'fair') but more slowly in a downward direction (it is hard to accept that we deserve less than what we used to get). This asymmetry in the adjustment of norms in combination with downward stickiness in nominal wages can make for inflationary pressures, even if average relative wages are trendless. Thus, policy regimes that aggravate volatility - including balanced budget rules for fiscal policy - tend to produce a higher level of 'baseline' inflation.
} 
target rate if the latter is considered credible), and it might seem that expectations cannot remain anchored to the target. Small deviations from fairness will be associated with only minor discrepancies of actual from expected inflation, but natural-rate theory does not permit persistent deviations, no matter how small; expected inflation would increase and inflation would be explosive. Here again, however, the behavioral evidence challenges the standard story.

Norms of fairness attach to both nominal and real magnitudes. There is strong evidence, for instance, that a fall in nominal wages is seen as unfair and that the level of nominal wages exhibits downward stickiness (Akerlof, Dickens, et al. (1996); Shafir, Diamond, and Tversky (1997)). ${ }^{25}$ In more general terms, the fairness of prices or wages is assessed in relation to past nominal values as well as in relation to the current values of other prices and wages, but the weights of the different evaluations are context dependent (Shafir, Diamond, and Tversky (ibid.), Kahneman, Knetsch, and Thaler (1986)). Inflation becomes less salient and purely nominal evaluations gain greater weight if inflation rates are low. By the same token, if deviations from established inflation anchors are small, they become less salient and may be ignored. In fact, small deviations between actual and expected inflation are likely to go completely unnoticed. Surveys document limited knowledge of actual inflation rates, and with finite cognitive resources it would not even be sensible for most people to try to keep track of small scale changes in the rate of inflation. ${ }^{26}$

Important aspects of this argument and its implications for wage inflation were anticipated by Rowthorn (1977). Nominal evaluations and the inattention to price inflation become dominant when inflation is low; when inflation is high, by contrast, it becomes costly to ignore price changes and expected price inflation becomes an important determinant of wage inflation. As a simple formalization, Rowthorn suggested that inflation will not be taken into account in wage bargaining as long as it stays below some threshold level.

In the present context, these behavioral arguments suggest that as long as the deviation of the actual from target inflation is kept small, expectations can remain anchored at the target level. ${ }^{27}$ In short, relative wage norms may be important in developing economies, but the norms are path dependent and minor deviations of actual from expected inflation may go unnoticed or, if noticed, may have no impact on expected future inflation. These behavioral findings have dramatic consequences. Developing economies do not suffer from a high

${ }^{25}$ In order to include this aspect, the inflation equations could be written

$$
\begin{array}{cl}
\hat{w}_{M}=\max \left\{0, \phi_{M}\left(\frac{w_{M}^{f}}{w_{M}}\right)+\hat{p}^{e}\right\} ; & \phi_{M}(1)=0, \phi_{M}^{\prime}>0 \\
\hat{w}_{S}=\max \left\{0, \phi_{S}\left(\frac{w_{S}^{f}}{w_{S}}\right)+\hat{p}^{e}\right\} ; \quad \phi_{S}(1)=0, \phi_{S}^{\prime}>0
\end{array}
$$

This extension would not affect the analysis in section 2.5 .

${ }^{26}$ Inattention may be 'rational'; Sims (2003). The substance of this argument - inattention is both sensible and behaviorally plausible - is surely right, even if the 'rational inattention' literature exaggerates the strict 'rationality' of the inattention.

${ }^{27}$ The extension of the fairness argument in section 2.8 reinforces this argument. 
'natural rate of underemployment' whose only remedy is 'labor market reforms'. Sustained non-inflationary transformation with a gradual elimination of underemployment in the informal sector and a gradual closing of sectoral wage gaps is perfectly possible.

The potential for explosive inflation following a large shock to relative incomes is also clear. A large shock to relative incomes leads to large increases in wage pressures and large discrepancies between actual and target inflation. The 'inattention threshold' may be breached, and the scene is set for an accelerationist inflation dynamics. The feedback effects from nominal incomes in the formal sectors to average incomes of informal workers prevents wage inflation in the tradable sector from restoring 'fair' relative wages, and although fairness norms will be changing, its speed of adjustment is likely to be much lower than that for inflation expectations.

\subsection{Extensions and robustness}

\subsubsection{Specification of consumption demand}

The benchmark specification of consumption assumed constant expenditure shares. This Cobb-Douglas specification of demand with unit elasticities of substitution between any two goods can be questioned. The substitutability between imported and domestically produced tradable goods, for instance, is likely to be higher than that between imported and nontradable goods.

If the assumption of fixed expenditure shares is dropped, changes in the real exchange rate will affect the composition of demand, and another question needs attention. In the benchmark specification, the average income in the informal sector becomes independent of the price of informal goods. This is no longer the case if the expenditure share for informal goods depends on relative prices. The informal sector is characterized by underemployment and if $\alpha_{A}$ depends on relative prices, it matters whether an increase in the demand for informal goods is met by an increase in price or by reductions in underemployment. We focus on the simplest case in which $p_{A}$ is constant in the short run and changes in demand are met by quantity adjustments (changes in $A$ ). By assumption $p_{M}$ and $p_{S}$ are predetermined and the relative prices of all three domestic goods will be given in the short run. A simple continuity argument ensures that the result for fixed $p_{A}$ will apply also when $p_{A}$ depends on demand if the dependence is weak or the sensitivity of the expenditure share $\alpha_{A}$ to changes in relative prices is low.

Now consider the key result in section 2.6: a commodity boom generates a decline in the tradable sector if interest rates are raised to neutralize the inflationary pressures from increased domestic demand. As shown in Appendix $\mathrm{D}$, this result continues to hold if a real appreciation (a fall in $\eta$ ) (i) reduces (or leaves constant) the share of consumption expenditure going to domestically produced tradable goods (tradable goods and imports are substitutes) and (ii) raises (or leaves constant) the share of spending going to nontradable goods (imports and nontradables are complements). These conditions, which 
arguably cover the cases that are most plausible empirically, are sufficient, but not necessary, for the result to hold.

Although the result is fairly robust to changes in the specification of consumption demand, there are conditions under which it does not hold. If imports and domestically produced tradable goods are complements and investment and exports are insensitive to changes in the interest rate and the real exchange rate, respectively, then a commodity boom could raise output in the tradable sector and reduce output of nontradables (see Appendix D).

\subsubsection{Consumption real wages as a determinant of fair wages}

The fair wage in the tradable sector may depend on the consumption real wage as well as on relative wages; that is,

$$
w_{M}^{f}=f^{M}\left(w_{A}, w_{S}, p\right)
$$

where $p$ is the relevant consumer price index. Workers consume a combination of imported, tradable and non-tradable (formal and informal) goods, and the price index is a linearly homogeneous function of the four prices:

$$
p=\xi\left(E p^{*}, p_{M}, p_{S}, p_{A}\right)=\xi\left(p_{M} \eta, p_{M}, p_{S}, p_{A}\right)
$$

This extension of the analysis implies that the inflation targeting condition in equation (26) can be written as

$$
f^{M}\left(\frac{w_{A}}{w_{M}}, \zeta\left(\frac{w_{A}}{w_{M}}\right), \xi\left(\eta, 1, \frac{p_{S}}{p_{M}}, \frac{p_{A}}{p_{M}}\right)\right)=1
$$

An appreciation of the exchange rate now increases the consumption real wage and reduces the inflationary pressures. The qualitative effects of a commodity boom are unchanged, however.

Including the consumption real wage as a determinant of fair wages has a notable implication, however. Productivity gains raise real wages and therefore facilitate gradual, non-inflationary reductions in the relative wage of workers in the tradable sector during a process of industrialization; the inflationary effects of declining relative wages can be offset by increasing real wages. Productivity growth cannot, however, offset the inflationary effects of sharp shocks to relative incomes.

\subsubsection{Intermediate goods}

The formal sectors in developing countries often rely on imported intermediate goods. Thus, assume that $\gamma_{M}$ and $\gamma_{S}$ units of imports are required as intermediate inputs per unit of output in the tradable and nontradable sectors.

Exchange rate movements now affect prices and/or profit shares in the formal sectors. If the prices stay constant, an appreciation will raise the profits shares, but a positive shock to $Z$ will have the same qualitative effect on $M$ and $S$ : with inflation targeting, $S$ must rise and $M$ must fall (see Appendix E). 
If the markups on marginal cost are kept constant, both prices and profit shares become decreasing functions of the real exchange rate $\eta$. In this case, it is a sufficient condition for $d S / d Z$ to be positive that $d \frac{p_{S}}{p_{M}} / d \eta \geq 0$. But weak effects on $X$ and $I$ allow for the possibility that both $S$ and $M$ may increase (see Appendix E).

If an appreciation (a fall in $\eta$ ) raises $p_{S} / p_{M}\left(d \frac{p_{S}}{p_{M}} / d \eta<0\right)$, then fixed expenditure shares imply a shift in real consumption from $S$ towards $M$. If this shift is sufficiently strong to offset the negative effects of an appreciation on $X$ and rising interest rates on $I$, the outcome can be a fall in $S$.

Intermediate imports also affects net exports. We now have

$$
N X=p_{M} X(\eta)-\theta(C+G)-\left[\alpha_{M}(C+G)+p_{M}(I+X)\right] \gamma_{M} \eta-\alpha_{S}(C+G) \gamma_{S} \frac{p_{M}}{p_{S}} \eta+p_{M} \eta Z
$$

Imported intermediate inputs add negative effects of exchange rate depreciation on net exports; that is, the Marshall Lerner condition will be less likely to hold. ${ }^{28}$

A depreciation, finally, will put downward pressure on real wages and add inflationary pressures, if the markup on marginal cost is constant and wage demands respond to changes in the real consumption wage.

\subsubsection{Imported and nontradable investment goods}

The benchmark version of the model assumes that all investment goods are produced domestically by the tradable sector. As an alternative, consider a case in which all investment goods are imported. The qualitative effects on the $M$ and $S$ sectors of a shock to commodity exports are unchanged: inflation targeting still implies a contraction in the tradable sector and an expansion of nontradables (see Appendix F).

It should be noted, however, that if capital goods are imported, an increase in interest rates may influence investment, but there will be no effect on the demand for domestically produced goods. Thus, economies with high shares of imported capital goods must rely on exchange rate movements as the mechanism through which monetary policy impacts inflation. These economies will require larger movements in interest and exchange rates in order to keep inflation within the target range following shocks to domestic demand.

If investment goods are domestically produced but partly nontradable, there are no qualitative changes in the short run without monetary policy. With inflation targeting, however, the qualitative results can be different, depending mainly on the sensitivities of net exports to exchange rates and of investment and the exchange rate to changes in interest rates (see Appendix F).

\footnotetext{
${ }^{28}$ Even in countries with a relative high share of intermediate goods imports, including the Brazilian case analyzed in the next section, there is empirical evidence that the MarshallLerner condition holds. See, for example, Gomes and Paz (2005) and Moura and Da Silva (2005).
} 


\subsubsection{Endogenous markups and labor productivity}

Markups and profit shares need not be constant. Firms may take advantage of boom times and increase their mark-ups and profit-shares. An increase in profit-shares, in turn, reduces aggregate consumption. Thus, allowing for endogenous markups soften the multiplier effects of shocks to demand. By continuity, however, the qualitative results of the model hold as long as the sensitivity of profit-shares to output is low.

The benchmark model assumed constant labor productivity. Introducing diminishing returns to labor makes the profit share endogenous, even if the markup on marginal cost is constant. Formally, let

$$
p_{i}=(1+m) \frac{w_{i}}{F^{i \prime}}
$$

where $F^{i}\left(L_{i}\right)$ is the production function for sector $i$. The profit share is

$$
\pi_{i}=1-\frac{F^{i \prime} L_{i}}{(1+m) F^{i}}
$$

The profit share will be constant if the production function has constant elasticity, but increasing (decreasing) in $L_{i}$ if the elasticity $F^{i \prime} L_{i} / F^{i}$ is decreasing (increasing) in $L_{i}$. Having diminishing returns to labor also affects the sensitivity of $w_{A}$ to changes in $Z$ because of its influence on $L_{A}$ which is no longer given by $N-M-S$. Again, however, the qualitative effects on $M$ and $S$ of shocks to commodity exports are unchanged, as long as the sensitivity of profit shares to changes in output is low.

\section{A brief summary of the recent Brazilian ex- perience}

\subsection{Stylized facts}

Brazil entered the 21st century with high hopes. The re-democratization process initiated in the 1980s had matured, the hyperinflation of the late 1980s and early 1990s had been squashed, and the dominant view was that by opening the economy and reducing state interference, the country would be put on a trajectory of sustainable growth and gradual catch-up with advanced economies. In terms of macroeconomic policy, the strategy was expressed in a 'tripod' rule: floating exchange rates, primary fiscal surplus, and inflation targeting.

The commodity boom added a new element. The Brazilian terms of trade began to improve from 2002, peaking in 2011 and falling again to a local minimum in 2015. As shown in figure 1, the net exports of commodities went from US\$ 12,9 billion in 2002 to US $\$ 99$ billion in 2011, with the share of commodities on total exports going from $40 \%$ to $60 \%$ in the same period. ${ }^{29}$ Surging commod-

\footnotetext{
${ }^{29}$ Data from the Ministry of Industry, Foreign Trade, and Services of Brazil - MDIC. Commodities are defined as: Mineral fuels, lubrificants and related materials; Food products and live animals; and Non-edible raw materials (except fuel).
} 
ity exports opened up space in the balance of payments to increase imports; over the same period the boost to domestic aggregate demand and an appreciation of the exchange rate led to movements in net exports of non-commodities from a US\$ 250 million surplus to a US\$ 69.2 billion deficit.

Figure 1: Terms of trade (June 2012=100) and Net exports (US\$ Bi. FOB)

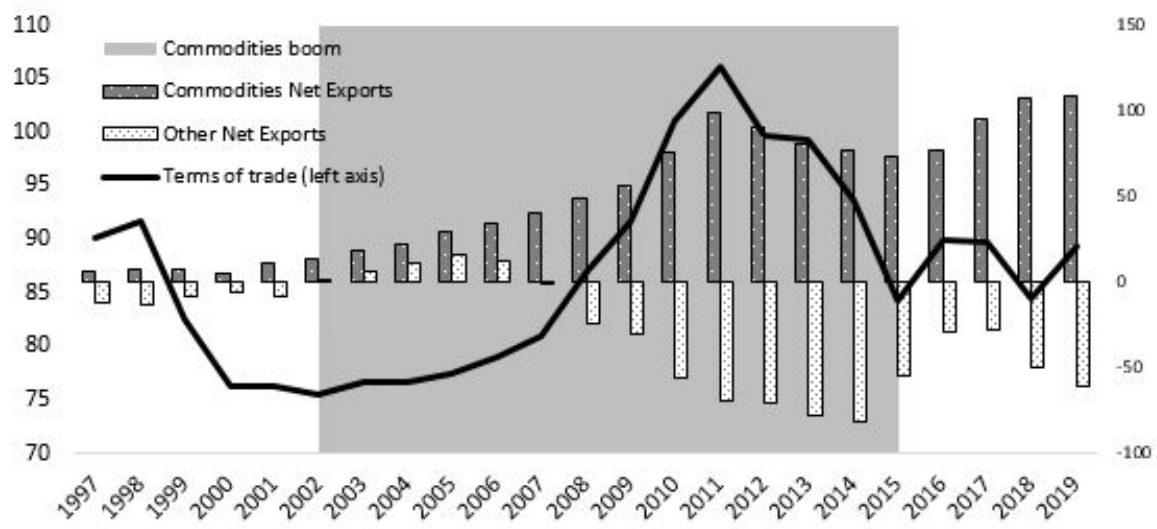

Source: IMF and Ministry of Economy, Industry, Foreign Trade, and Services of Brazil.

Authors' calculation.

Two main channels link the increase in revenue from commodity exports to domestic absorption: the increase in private consumption due to the higher income in the sectors directly associated with the exports of commodities, and the increase in government expenditure following the windfall revenue from taxes and royalties. These initial movements were amplified by multiplier effects on consumption and investment.

The period from 2003 to 2011 saw an acceleration of GDP growth, with an average of $3.5 \%$ from 2002 to 2014 - and $4.5 \%$ between 2007 and 2011 - compared to $2.6 \%$ in the previous decade (1992-2001). Private consumption was the fastest-growing component of demand during the commodity boom, both in relative and absolute terms. Aided by rising incomes at the lower end of the income distribution and an expansion of consumer credit, private consumption increased from $61.7 \%$ of the GDP in 2002 to $64.7 \%$ in 2011 , reaching $67.4 \%$ in $2015 .^{30}$ Illustratively, car sales increased by $130 \%$ between 2002 and 2011, and the sales of home appliances rose by $242 \%$ in real terms. ${ }^{31}$ Federal government expenditure also accelerated, reaching an annual average real growth rate of $8 \%$ during the ascendant phase of the boom (2003-2010), compared to $5.8 \%$ from 1998 to 2002 and $3.6 \%$ between 2011 and 2015. ${ }^{32}$ Public investment also in-

\footnotetext{
${ }^{30}$ From 2002 to 2010 , private investment grew more rapidly, from $18.2 \%$ to $21.8 \%$ of GDP, but lost ground from 2011, reaching 19.3\% in 2015. Brazilian National Accounts, IBGE.

${ }^{31}$ Respective sources: FENABRAVE - National Federation of Motor Vehicle Distribution and ABINEE - Brazilian electrical and electronics industry association.

${ }^{32}$ Using data from Ministry of Economy, Industry, Foreign Trade and Services of Brazil.
} 
creased between 2005 and 2010, but the expenditures were largely concentrated in consumption. ${ }^{33}$

The fiscal expansion did not violate balanced budget prescriptions, however; the federal government maintained continuous primary fiscal surpluses - on average $2.2 \%$ of GDP from 2002 to $2011^{34}$. There is robust evidence that local governments also used the increase in revenues directly and indirectly related to the commodity boom to increase expenditure while preserving fiscal discipline. The average primary surplus of the public sector, which includes federal and local governments, was $3.1 \%$ of GDP between 2002 and 2011, and the net public indebtedness fell from $55.8 \%$ of GDP in 2002 to $36.4 \%$ in $2011 .^{35}$

Figure 2: Private consumption $(\mathrm{C})$, government consumption $(\mathrm{G})$, and Nonresidential investment (I) - \% GDP

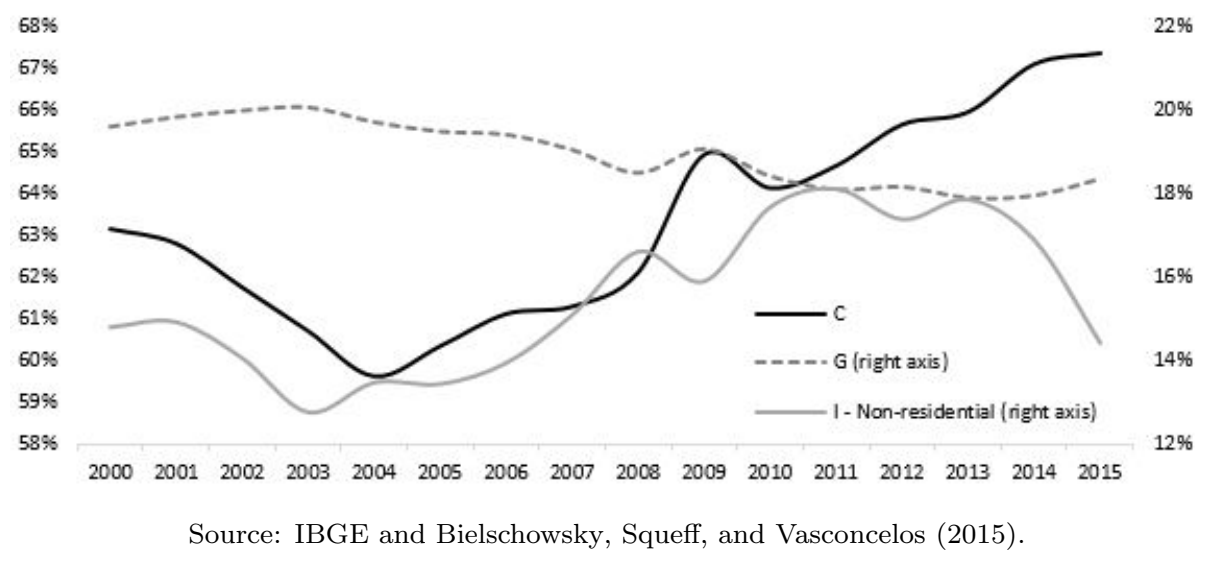

The growth rates were uneven across sectors. In the years before the intensification of the commodity boom, from 2000 to $2004,{ }^{36}$ the manufacturing sector grew at an annual average rate of $4 \%$, significantly above those of retail $(2.6 \%)$ and services $(2.2 \%) .{ }^{37}$ The ranking was reversed during the ascendant

\footnotetext{
${ }^{33}$ Federal public investment went from $0.45 \%$ of GDP in 2002 to $0.79 \%$ in 2010 . Total expenditure of the federal government in the same period went from $15.9 \%$ of the GDP to 18.2\%. Ministry of Economy, Industry, Foreign Trade and Services of Brazil and Observato rio de Politica Fiscal - IBRE/FGV.

${ }^{34}$ The average total federal deficit including interest payments was $3.2 \%$ of GDP in the same period. The public debt ratio fell however, which is in line with fiscal policy prescriptions.

${ }^{35}$ Data from Banco Central do Brasil. Orair and Gobetti (2017) provide slightly different numbers; they suggest a reduction in public debt from $60 \%$ of GDP in 2002 to $31 \%$ in 2013 .

${ }^{36}$ Manufacturing might have benefited from the depreciations of the exchange rate in 1999 and 2002. The increase in manufacturing employment, for instance, is concentrated in 2004 and 2005, and the most positive net exports result since 1997 was achieved in 2006, with a surplus of US $\$ 14.5$ billions. Thus, looking at sectoral data, it is important to bear in mind that effects from previous shocks still operate during the initial years of the commodity boom.

${ }^{37}$ Identified as other services in the Brazilian national account system, which comprises all usual private services such as education, health, lodging and food services, domestic services, amoung others.
} 
part of the boom years from 2005 to 2011 when the rate of growth of manufacturing sector was $2.3 \%$, and those of retail and services increased to $4.7 \%$ and 4\%. From 2011 to 2015 the gap is even wider, with manufacturing decreasing annually $3.1 \%$ while retail and services changed, on average, $-0.2 \%$ and $0.8 \%$.

Trade contributed to the heterogeneous sectoral development. The real exchange rate appreciated and manufacturing faced intensified international competition. During 2005-2008, more than 22\% of the increase in domestic consumption of manufactures was supplied by net imports, compared to only $6.1 \%$ in the period 2003-2005. In the cases of durable goods, this share of net imports went from $0 \%$ in 2003-2005 to $49.3 \%$ in 2005-08 (Bielschowsky, Squeff, and Vasconcelos (2015)). Services, by contrast, are largely nontradable and performed better, as can be seen in terms of profitability and value-added in figure 3. Around 6 percentage points of GDP was 'transferred' from the manufacturing sector to non-tradables between 2004 and 2014. The profit-share of the manufacturing sector decreased from $52.2 \%$ in 2004 to $29.9 \%$ in 2014 , while in nontradables it was relatively stable - a large increase in the profit share in services (from $19.6 \%$ to $30.6 \%$ in the same period) was offset by its decline in public utilities ${ }^{38}$ and construction sectors. Investment shows a similar pattern in favor of non-tradable activities: according to Miguez (2016), before the intensification of the commodity boom (2001-2004), the average annual growth rate of investment in real terms was $-4.2 \%$ for the manufacturing sector and $-7.5 \%$ for a sector combining retail and other services activities; during the boom period (2005-2011), these rates went to $6.6 \%$ and $14.6 \%$, respectively. ${ }^{39}$

Figure 3: Non-tradable and Tradable sectors - VA and profitability $(2002=1)$

VA $(\%$ GDP)

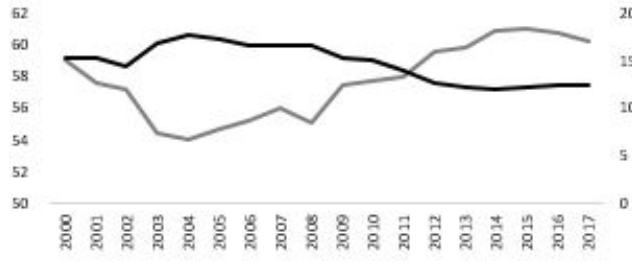

- Non-tradable Tradable (right axsi
Profit-share

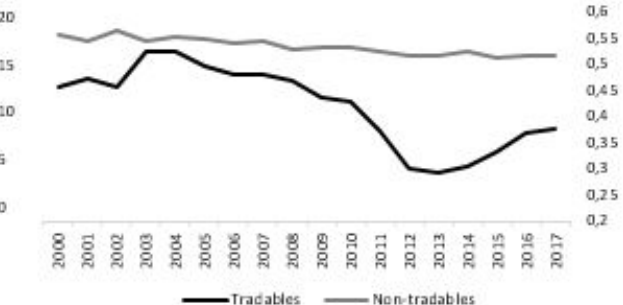

Source: Author's calculation based on IBGE. 'Non-tradables' consistent of the services sector, retail and construction. In line with the model definition, 'tradables' is the manufacturing sector.

Faster economic growth was reflected in the labor market. Measured unemployment decreased from around $12 \%$ in 2002 to less than $5 \%$ in 2014 , and formalization went from $52 \%$ to more than $63 \%$ in the same period (Komatsu and

\footnotetext{
${ }^{38}$ Electricity, water, sewage.

${ }^{39}$ Rugitsky (2017) suggests another source of uneven sectoral performance. Many services have high income elasticities of demand at intermediate income levels, and domestic demand, therefore, shifted towards services as growth rates increased and inequality fell.
} 
Menezes Filho (2015)). ${ }^{40}$ Once again sectoral differences are relevant. The ratio of (formal plus informal) nontradable to tradable employment stayed roughly constant, but there was a significant shift from the informal to the formal nontradable sector (figure 4). In terms of the model in section $2, L_{A} / L_{S}$ fell while $L_{M} /\left(L_{A}+L_{S}\right)$ was stable. This dynamics, combined with the increase in the share of value added of the nontradable sectors (formal and informal), displayed in figure 3, suggests a reduction in the level of underemployment in the nontradable, informal sector.

The commodity boom and the associated increase in private and government consumption produced inflationary pressures (see figure 5). Wages rose significantly, but despite the superior dynamics in the nontradable sector in the period, sectoral relative wages shifted only slightly against manufacturing workers (see figure 4). Manufacturing workers managed to raise their nominal wage roughly in step with wage increases in the nontradable sectors. In terms of the model, the relative wage $\frac{w_{M}}{w_{S}}$ stayed roughly constant while $\frac{w_{M}}{w_{A}}$ decreased slightly. ${ }^{41}$ In the non-tradable sectors, this increase in wages was passed on to prices, as the profit-share figures indicate. Given international competition, a large part of wage increases in the manufacturing sector was absorbed by reductions in profitability, accentuating the conflict over the functional income in the sector. The number of strikes went from 302 (23.138 hours) in 2004 to 2.050 (111.342 hours) in 2013 (DIEESE (2005), DIEESE (2014)). Besides the market forces, minimum wage policy also had important impacts. With a real increase of $68 \%$ between 2004 and 2014, it affected low wage formal workers, informal workers (via a 'signaling' effect) and social transfers (including pensions), which are indexed by the minimum wage ${ }^{42}$. The exact weight of each of these effects are not clear, but there is some evidence that the impact via government transfers (which is incorporated in the model presented in section 2 as government consumption) accounts for about half of its effect on the lowest income levels (Saboia and Hallak Neto (2018)).

After a spike in inflation in 2002-2003 due to capital flight and a steep depreciation on the eve of the presidential election of Lula from the Workers Party (PT), inflation was kept consistently within the target range from 2004 to 2014. Price movements displayed sectoral heterogeneity, however. Inflation in the service sector remained consistently above average inflation, exceeding the target range from 2008 to 2016. High inflation in services was offset by the lower inflation for (non-commodity) tradable goods and the output of stateowned companies, including oil (Petrobras) and electricity (Eletrobras).

The downward pressure on tradable goods prices was a result, to a large

\footnotetext{
${ }^{40}$ Data for metropolitan areas.

${ }^{41}$ The reduction in wage inequality and extreme poverty is an important element of the Brazilian trajectory in the period. For the purposes of this paper, we focus on the relative wages in sectorial terms and their implications for structural change; see Souza and Medeiros (2015) for a critical discussion of the evidence on changes in personal income inequality during this period.

${ }^{42}$ These effects of minimum wage increase are more directly analyzed by Neri, Gonzaga, and Camargo (2001), Oreiro and D'Agostini (2017), and Serrano and Summa (2015), among others.
} 
Figure 4: Ratio of Non-tradable to Tradable sectors - Wages and Employment $(2002=1)$

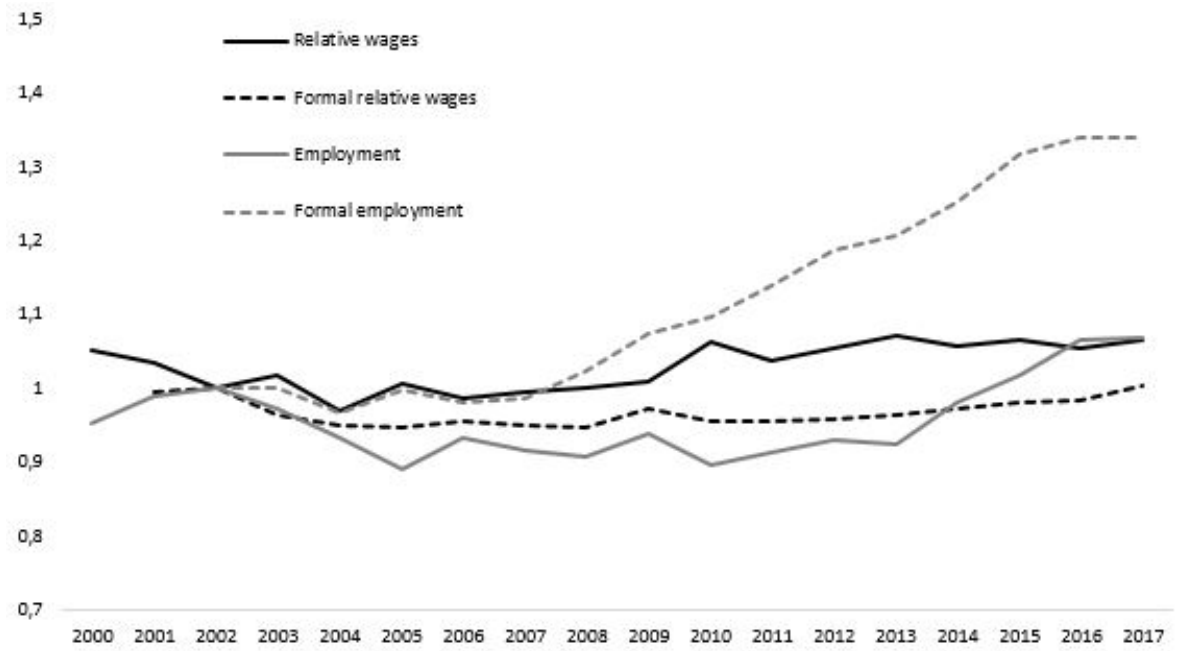

Source: Author's calculation based on IBGE and RAIS/Ministry of Work and Employment of Brazil.

extent, of monetary policy. The basic interest rate (SELIC) followed a downward trend from 2002 to 2008, but the premium over international rates (the LIBOR is used here) was kept high despite a significant reduction in country risk as measured by the EMBI+ index. ${ }^{43}$ A high interest premium encouraged the inflow of international capital, reinforcing pressures from the commodity boom towards exchange rate appreciation in both nominal and real terms. The policy was intensified as inflation pressures increased, particularly between 2010 and 2011 , as can be seen from the steep increase in the interest rate differential despite a stable country-risk (figure 6).

From 2011 to 2014, macroeconomic policy became erratic. For present purposes, it is sufficient to note that fiscal policy remained expansionary most of the time,${ }^{44}$ although with changes in its composition, and that monetary policy was loosened briefly in 2012 and early $2013 .{ }^{45}$

Macroeconomic policy returned to more strict principles of inflation target-

\footnotetext{
${ }^{43}$ The source for the annual Brazilian basic interest rate is the Central Bank of Brazil, and the annual London Interbank Offered Rate (LIBOR) based on U.S. dollars was obtained via the FRED (Federal Reserve Economic Data - St. Louis FED). The EMBI+ index is produced by JP Morgan.

${ }^{44}$ There was a brief period of fiscal consolidation in 2011.

${ }^{45}$ The policy adopted in this period reversed some of the previous dynamics, by reducing interest rates and depreciating the exchange rate. Others, however, were reinforced, namely by cutting public investments while keeping balanced budgets. It can also be argued that erratic movements in the economic policy undermined predictability regarding future demand and interest and exchange rates, limiting the potential benefits of the change in monetary policy.
} 
Figure 5: Inflation

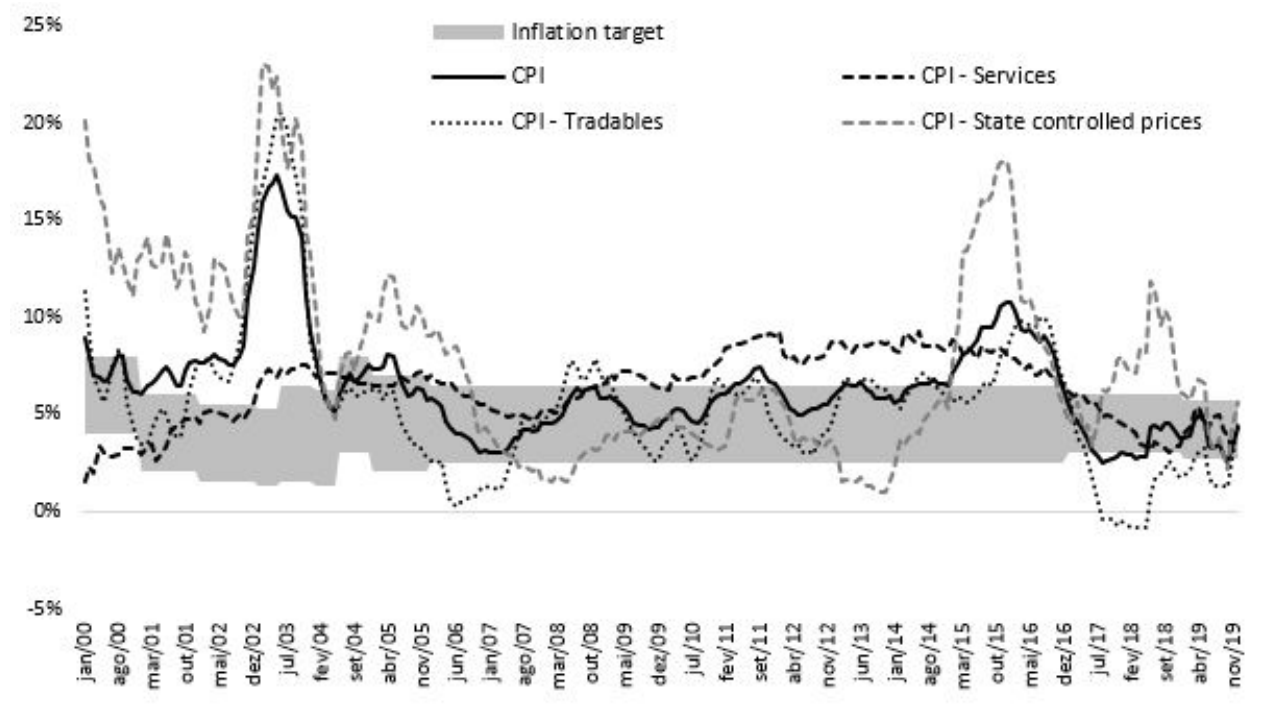

Source: IBGE and the Brazilian Central Bank. Author's elaboration.

ing and balanced budgets in 2015. The end of the commodity boom, a deceleration in consumer credit, and lower economic growth meant that balanced budgets now implied fiscal contraction. The liberalization of state-controlled prices and an exchange rate depreciation (following the reversal of terms of trade) produced a spike in inflation in 2015, despite a tightening of monetary policy. Inflation returned to its target in 2017 in the wake of the severe crisis that had reduced real GDP by $6.7 \%$ over those two years.

Stagnation since then has left GDP in 2019 well below the level in 2014 the average annual growth rate was $1.2 \%$ between 2017 and 2019. Many of the social improvements have also been reversed, with a consistent rise in income inequality; extreme poverty reached 13.8 million people in 2019, an increase of $53 \%$ since 2014 .

\subsection{Interpretations}

\subsubsection{Our story}

The stylized facts of the recent Brazilian trajectory are consistent with the theoretical framework proposed in section 2. A commodity boom allows an expansion of private and government consumption with a stable or falling debt ratio. The boost in consumption reduces underemployment in precarious occupations, increases the average income in the informal sector and creates wage pressures in the formal sectors. In the Brazilian case the pressures were reinforced by rising minimum wages and policy-induced relaxations of credit constraints. Tight monetary policies counteract the incipient inflationary tendencies; these policies 
Figure 6: Relative interest rate, country-risk and real exchange rate

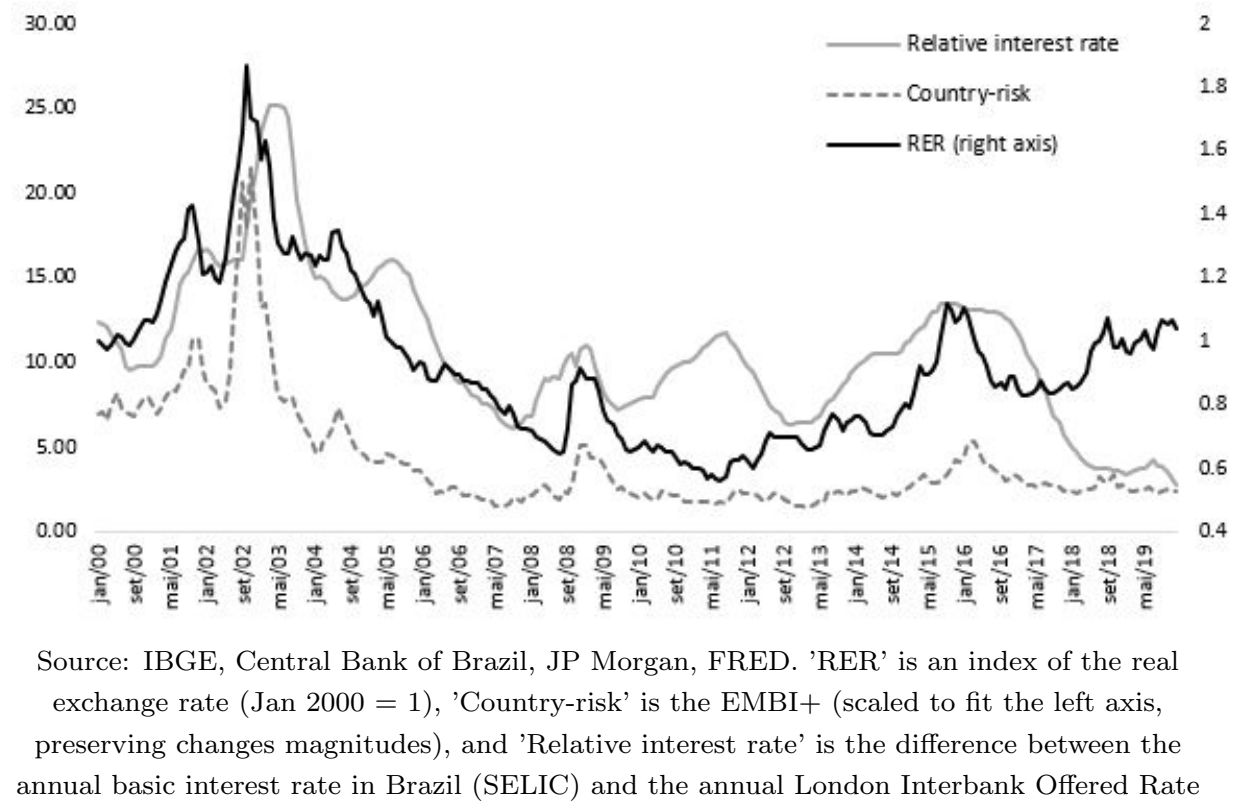

(LIBOR), based on U.S. Dollar.

impact the manufacturing sector disproportionately as interest rates rise and the exchange rate appreciates. Endogenous profit margins reinforce the effects of higher nontradable inflation on relative prices, and manufacturing experiences a substantial decline in profitability. Falling capacity utilization and profitability means that investment in the tradable sector also falls.

If our interpretation is correct, macroeconomic policy during the boom years contributed to deindustrialization and left the economy in a fragile position when commodity prices fell. The policy prescriptions also failed when the crisis hit. Attempts to balance the budget aggravated the downturn and prolonged the recession, while reallocations of government spending away from public investment and towards consumption reinforced the shift in favor of the nontradable sectors.

The commodity boom and bust in Brazil exemplify the large external shocks that buffet many developing economies. The standard macroeconomic prescriptions magnify the effects of external shocks with serious adverse implications for economic development.

Needless to say, other factors and policies also influence economic development. Education, health and industrial policies can be crucial, and these policies interact with the macroeconomic variables. Guzman, Ocampo, and Stiglitz (2018), for instance, stress the complementarity between exchange rate and industrial policies in boosting sectors with positive externalities and high level and growth rate of productivity. Staying with the Brazilian example, moreover, 
the sources of the multidimensional, still ongoing crisis also include corruption scandals, political polarization and class conflict. ${ }^{46}$

\subsubsection{Other interpretations}

A typical narrative grounded in the 'New Neoclassical Synthesis' (Goodfriend and King (1997)) explains the increase in growth rates from 2002 by a combination of (i) solid macroeconomic foundations built and consolidated after 1994 and lasting until at least 2006, with (ii) a favorable international environment and (iii) a demographic dividend from having a high share of the population being of working age (Pessôa (2018); Pessôa (2017); Mesquita et al. (2014)). From 2008, however, credit expansion, public investment and other expansionary policies led to inflationary pressures and crowding-out of private investment.

The crisis, according to this interpretation, was brought about in part by the exhaustion of the consumption-led dynamics based on public expenditure and increasing debt but, more importantly, by the weakening of the 'macroeconomic foundations' as a result of fiscal expansion, misguided state intervention, and a lack of reforms that, allegedly, could have increased productivity. ${ }^{47}$ Similar conclusions can be found in other studies, including the World Bank (2017). The explanation of the rise and fall of the Brazilian economy in Garber et al. (2019) also focuses on aggregate demand, particularly the expansion of household credit which was facilitated by the favorable international environment.

All these accounts, like ours, emphasize the commodity boom and the expansion of aggregate domestic demand. Unlike in our interpretation, however, there is no detailed analysis of the sources of the inflationary pressures and the role of inflation targeting, and sectoral interactions and exchange rate movements are secondary, if relevant at all.

Points of convergence are harder to find between our interpretation and studies that have a New Keynesian Phillips curve (NKPC) at the core. Most econometric studies on Brazilian data find little support for the NKPC (Sachsida (2013) and Maka, Barbosa, et al. (2013), among others). ${ }^{48}$ The NKPC, nonetheless, is included as a key element of DSGE models that are used to guide both monetary policy and private decisions, including the SAMBA model developed by the Brazilian Central Bank (De Castro et al. (2015)). ${ }^{49}$ These models, in our view, make assumptions that preclude the essence of the development problem: underemployment and problems of structural transformation

\footnotetext{
${ }^{46}$ See, for instance, Singer (2020)

${ }^{47}$ According to this argument productivity enhancing reforms should have been carried out in education, the legal system and the labor market. The misguided intervention involved industrial policy, regulatory interferences in the energy sector and elsewhere, forced reductions in interest rates, and the use of tax exceptions to firms from 2011.

${ }^{48}$ Maka and Barbosa (2017) provide a slightly more positive assessment. Testing four types of Phillips curves (accelerationist, new Keynesian, hybrid, and sticky information) for Brazil between 1996 and 2015 and using a larger than usual confidence interval, they could not reject the sticky information version.

${ }^{49} \mathrm{~A}$ special issue of the Brazilian Review of Econometrics (November 2015) presents and discusses a number of Brazilian DSGE models, including the SAMBA model.
} 
disappear from sight in models of cyclical fluctuations around a steady growth path with 'natural unemployment'.

The (post-)Keynesian literature views the expansion of aggregate demand as central to the increase in economic growth, emphasizes exchange rate movements, and sees cost-push factors as the dominant force behind inflation. There are disagreements within this literature, however, with respect to the limits of the process and the reasons for the downturn. At one extreme, the recession and subsequent stagnation are seen as consequences of the fiscal contraction in 2011 and the ensuing attempts to boost private investment. In these accounts, the sectoral changes were of secondary importance for the macro dynamics, and it is suggested that by reducing cost-push inflation, the exchange rate appreciation had more positive than negative effects. At the other extreme, it is argued that despite positive short run effects on capacity utilization, a policy regime of fiscal expansion, high interest rates and an overvalued exchange rate was fated to fail in the medium run; adverse effects on the profitability of manufacturing, the level of investment, and the balance of payments would make this regime unsustainable. Serrano and Summa (2015) represents an example closer to the first group; Martins and Rugitsky (2018) is closer to the second. ${ }^{50}$

Other contributions also combine increasing aggregate demand, exchange rate movements and cost-push inflation. Rossi, Mello, and Bastos (2020) argue that the constitution of a mass consumer market was a deliberate economic strategy of the PT governments led by Lula and Rousseff. The idea was that the expansion of domestic demand could play a developmental role via economies of scale and the reduction in underemployment. The failure to meet the first objective, they argue, was due to limitations of the process itself (the consumption boom based on an appreciated exchange rate) and a lack of complementary policies (capital controls to avoid volatility, for instance). ${ }^{51}$

Discussing monetary policy, Serrano (2010) suggests that inflation control is ultimately achieved via the exchange rate appreciation caused by high interest rates. The combination of high interest rate and an appreciated exchange rate, however, increases the burden of public debt and the opportunity cost of capital, harms the manufacturing sector and has the potential to deteriorate the external balance. $^{52}$ Summa and Serrano (2018) reinforce the argument, emphasizing the centrality of the price effect of the exchange rate: an increase in interest rates, they argue, has negligible effects on investment, while an exchange rate

\footnotetext{
${ }^{50} \mathrm{~A}$ similar argument is made in Martins (2017).

${ }^{51}$ Dweck, Chaves, and Chernavsky (2013) also focus on the possible 'virtuous cycle' of demand expansion, economic growth and productivity gains, but seem to present a more positive view of the process until 2013.

${ }^{52}$ Similar conclusions are presented by Summa (2011). The dangers of an overvalued exchange rate are also emphasized by Barbosa-Filho (2011). Using data from 1999 to 2014, Barbosa-Filho (2015) estimates the pass-through of the exchange rate to prices in the Brazilian case and presents some evidence in favor of the hypothesis elaborated in Barbosa-Filho (2014) that the real exchange rate level has a positive impact on long-term inflation. In a similar line, J. M. Braga (2013) empirical study suggests that inflation between 2000 and 2010 was determined mainly by two elements: exchange rate and commodity prices. In the second half of the period, wage growth also became important, especially for services prices.
} 
appreciation stimulates aggregate demand via higher real wages. Nassif, Feijó, and Araújo (2020), in a broader assessment of recent macroeconomic policy in Brazil, follow a similar argument, presenting evidence that inflation control in Brazil is achieved via the exchange rate and that fiscal policy design is procyclical; they say little about the sources of inflation, however, suggesting that inflation is a "very complex phenomenon" (p. 751, 758).

Summa (2016) develops a model of distributive conflict and cost-push inflation. Disaggregating output into monitored goods, industrial goods, food, and services, he suggests that the price movements of tradables follow inflation in the rest of the world and the exchange rate, while the price of nontradables are determined by minimum wages and productivity, prices of imported inputs in domestic currency, firm's mark-up, and supply shocks (such as crop failures). Increases in the minimum wage have a direct impact on consumption and on the price of 'low-skill' services and, in conjunction with other measures, raised workers' bargaining power, leading to stronger wage inflation from 2006.

Sectoral distinctions are also central to the analysis in Carvalho and Rugitsky (2015), Rugitsky (2017), Loureiro (2020), and Brenck and Carvalho (2019). These studies emphasize linkages between falling wage inequality, economic growth, and inflation in the services sector. ${ }^{53}$ Income growth for the poorest half of the population shifted the consumption pattern to both manufactured goods with higher technological content and nontradables that are intensive in low skill labor. The shifts, it is argued, generated a deterioration of the trade account, as those manufactured goods were mostly imported, but also boosted the growth rate of low incomes because of the increased demand for low-skill services. ${ }^{54}$

As should be apparent, our analysis has elements in common with many of these contributions. Monetary policy controls inflation in large part through induced movements in the exchange rate as in Serrano (2010); inflation targeting can hurt investment and economic growth, as in Barbosa-Filho $(2011)^{55}$; the role of the increase in incomes at the bottom of the distribution can have inflationary effects, as in Summa (2016); sectoral interactions are important as in Carvalho and Rugitsky (2015). ${ }^{56}$ Other elements of our framework have affinities with the 'new developmentalism' (Bresser-Pereira, Jose Luis Oreiro, and Marconi (2014)) and with a broader and older literature on the relationship between commodity exports, exchange rate appreciation, and development. ${ }^{57}$

\footnotetext{
${ }^{53}$ Marconi, Rocha, and Magacho (2016) also focuses on sectoral patterns, but particularly on the direct capacity of commodity exports to drive technological development

${ }^{54}$ Santos et al. (2018) point out that the services inflation in Brazil would be well explained by the effects proposed both by Clark (1940) (services as 'superior' goods) and Baumol and Bowen (1965) (services productivity grow less than the rest of the economy).

${ }^{55}$ Lima and Setterfield (2008) also analyze inflation targeting within a post-Keynesian framework, arguing that the greater the focus inflation, the less stable will be the system.

${ }^{56}$ Interactions between an elastic labor supply (dual economy) and the exchange rate have also been explored, for instance in Porcile and Lima (2010).

${ }^{57}$ Bresser-Pereira and Rugitsky (2018) discuss its history. See Ros (2013) for a broad discussion of traditional development theory and its more recent directions.
} 


\section{Conclusion}

Conventional macroeconomic policy prescriptions have been centered around principles of sound finance, with fiscal policies that keep public debt low, and a monetary policy focused on inflation targeting. These prescriptions are questionable. For advanced economies, structural aggregate demand problems may require sustained fiscal stimulus if full employment growth is to be maintained (e.g. Ryoo and Skott (2013); Summers (2015)), and inflation targeting may simply validate high unemployment and cause great harm if there is no natural rate of unemployment. But the damage from the policy prescriptions can be even greater in developing economies.

Advanced economies have 'full employment' as a guidepost for policy, even if the guidepost is highly imperfect. In dual economies the notion of full employment cannot help guide policy. Underemployment is pervasive, and the development problem is all about structural transformation and the expansion of the modern sector. In this setting, the twin pillars of sound finance and inflation targeting can impede the development process and lead to premature deindustrialization.

Behind these pillars lies a presumption that when it comes to macroeconomic policy, 'the rest' can be left to the market as long as the government keeps its own house in order (balances its books) and ensures price stability. This presumption is overly optimistic. 'The rest' cannot be left to the market. Macroeconomic policies influence the sectoral composition of output and investment, and these variables are crucial for any development strategy.

It is widely recognized that the application of the standard prescriptions to developing economies poses challenges. Fraga, Goldfajn, and Minella (2003), for instance, point out that volatile environments may make it harder for central banks to establish the credibility of inflation targets. But the problem with volatility runs deeper. There is no reason to expect symmetry between the effects of over and undervaluation of the real exchange rate; Razmi, Rapetti, and Skott (2012) find a negative effect of real exchange rate volatility as well as a positive long-run effect of undervalued exchange rates for developing countries. Balanced budgets and inflation targeting aggravate the volatility of the real exchange rate and of the demand conditions facing the modern sector in developing economies; the standard policy prescriptions become impediments to growth and structural transformation in these economies, even if overvaluation of the exchange rate is avoided on average.

By questioning inflation targeting we do not suggest that high inflation is desirable. The sources of inflation are critical, however, for the formulation of a successful development strategy without high inflation, and the New Keynesian Phillips Curve - even with ad hoc augmentations - provides an inadequate platform for understanding inflation; this is the case for advanced economies, but even more so for developing ones.

If our argument in this paper is correct, distributional conflict over relative wages are central to inflation in developing economies. Although the modern sector faces an elastic supply of labor, social norms regarding relative wages can 
create strong inflationary pressures in the formal sector if shocks to domestic demand produce a sharp increase in the average incomes of workers in the informal sector. Inflation is the result of a nexus of demand-determined incomes in the informal sector, relative-wage norms, and cost push inflation in the formal sectors.

Windfall gains from a commodity boom exemplify the dangers from following the standard policy prescriptions. The gains relax balance of payments constraints and allow the expansion of domestic demand without running public deficits. The joy may be short-lived, however, if the expansion of demand produces inflationary pressures, rising interest rates and an overvalued exchange rate. This scenario - and an ensuing Dutch disease - is perfectly compatible with a macroeconomic policy package of balanced budgets and successful inflation targeting.

Crucially, fairness norms need not present a significant barrier to development. Structural transformation may be facilitated by modest rates of inflation, ${ }^{58}$ but the path dependency of social norms implies that the expansion of the modern sector and the gradual reduction in the wage premium for formal sector workers can be achieved without provoking high or explosive inflation.

Full employment is not a meaningful target in developing economies, but a commodity boom provides an opportunity to speed up the development process without squeezing current consumption or running into balance of payments problems. Policy can be adjusted so as to guide the windfall gains from a commodity boom towards faster expansion of the modern sector rather than immediate consumption, thereby reducing inflationary pressures and securing sustainable increases in average incomes and reductions in wage inequality as the formal sector expands. Private investment in the tradable sector will not accelerate, however, if exchange rate appreciation makes the sector uncompetitive. ${ }^{59}$ Thus, interest rates should be kept low and combined with other measures (e.g. capital controls) in order to avoid exchange rate appreciation and high volatility.

Going beyond the formal analysis in this paper, it is important to stress that significant short-term improvements for low-income groups can be made compatible with sustainable development and may indeed promote the development process. Changes in tax structures and public spending patterns influence relative incomes, and the way in which benefits flow to the poor is likely to affect inflation and, consequently, the reaction of macroeconomic policy. Im-

\footnotetext{
${ }^{58}$ Anecdotally, but quite strikingly, the average annual inflation rate in Korea was above $10 \%$ during 30 years of miracle growth from 1960 to 1990, with several spikes above $25 \%$. Studies consistently have found non-linear effects of inflation on economic growth. Even papers explicitly favor the thesis that the relation is negative have found that there is no statistical relationship for inflation levels below 8\% (Sarel (1996)) or 15\% (Barro (1995)), for instance. In another influential paper, Bruno and Easterly (1998) argue that there is no robust evidence in favor of such relationship for inflation levels below $40 \%$, and that the correlation is actually positive from 1961-1973. This result is corroborated by Pollin and Zhu (2006); they extend the period to 1961-2000 and find a positive relationship relationship between growth and inflation for low-income countries with inflation rates below $15 \%$.

${ }^{59}$ For evidence that exchange rate influences investment surges episodes, see, for instance, Libman, Montecino, and Razmi (2019)
} 
provements in health services and education, and investment in infrastructure - including sanitation, public transport, electricity and internet services - can be targeted towards low-income groups and are less likely to set off an inflationary spiral than a general boost to consumption, with its derived effects on the market incomes of workers in the nontradable sectors.

Access to public services has been secondary in much of the recent discussion of inequality and welfare policies; the focus instead has been on personal income. ${ }^{60}$ Public services, however, can be essential for reducing social inequality. ${ }^{61}$ And they are highly valued. The 2013 protests that, in some sense, initiated the recent and still ongoing political instability in Brazil were sparked by opposition to an increase in the cost of public transport. According to Antunes and R. Braga (2014), the underlying anger was rooted in a combination of stagnating social mobility, particularly among those that had recently moved into the formal market, and a demand for better public services. The protests arguably expressed the sentiment that "the quality of life inside the home has improved, but this is not reflected outside" (Haddad (2012), Couto (2014)). ${ }^{62}$ As Lavinas (2017) put it

[T]he upward social mobility observed in Brazil in the years spanning 2003-2014 failed to even come close to promoting a true expansion of the country's middle classes. In Brazil, the market has universalized access to color TVs and fridges among those in the lowest income quintile. Treated water, however, to say nothing of adequate sanitation, remains a luxury, the province of few. (p. 86)

It should be acknowledged, before closing, that the model in this paper has obvious limitations. An important one is the short run focus of the analysis. Accumulation rates may be relatively insensitive to short run variations in the utilization rates, but this insensitivity does not carry over to the long run. Endogenous changes in labor productivity - whether through learning-by-doing or induced changes in R\&D - would also need to be included in the analysis of long-run effects of overvalued exchange rates; as is well known, extensions of this kind can produce development traps (e.g. Ros (2013)). Fiscal policy, moreover, has not been discussed in any detail and industrial policy not at all, while balance of payments constraints have been touched on only tangentially.

Our purpose in this paper has been quite narrow. Combining and modifying ideas from a range of existing work, we have presented a model of inflationary pressures in developing economies. The methodology is different from that of

\footnotetext{
${ }^{60}$ Saad Filho (2016) and Currie and Gahvari (2008) present, from different perspectives, arguments for why policies other than cash-transfers might be important. For an assessment of the shift towards cash transfers in welfare policies, see Lavinas (2013), for instance.

${ }^{61}$ The long-term effects of improvements in health and education may be obvious, but access to public services like transportation also impact professional (as well as leisure) opportunities; Pereira et al. (2020).

${ }^{62}$ At about the same time a very similar diagnosis emerged, but related to the importance of public services and macro policy for the productive structure of the country: 'Within the factory gates, a continuous improvement in efficiency and productivity. Outside the same gates, unacceptable transaction costs' (Barros and Giambiagi (2008), p. XII).
} 
contemporary macroeconomics and, unlike DSGE models, we have focused on underemployment, sectoral differences and the need for structural transformation in developing economies. The model implies that a macroeconomic policy package that combines balanced budgets and inflation targeting can impede the economic development of middle-income countries. 


\section{Appendix A: Keynesian stability conditions}

We have

$$
\begin{aligned}
& M=F(M, S, Z, \eta, r)=\alpha_{M} \frac{\left(1-\pi_{M} s\right)(I(M, S, r)+X(\eta))+\eta Z \epsilon}{\theta+s\left(\alpha_{M} \pi_{M}+\alpha_{S} \pi_{S}\right)}+I(M, S, r)+X(\eta) \\
& S=G(M, S, Z, \eta, r)=\alpha_{S} \frac{p_{M}}{p_{S}} \frac{\left(1-\pi_{M} s\right)(I(M, S, r)+X(\eta))+\eta Z \epsilon}{\theta+s\left(\alpha_{M} \pi_{M}+\alpha_{S} \pi_{S}\right)}
\end{aligned}
$$

where

$$
\begin{aligned}
& F_{1}=\frac{\alpha_{M}}{\alpha_{S}} \frac{p_{S}}{p_{M}} G_{1}+I_{1}>0 ; \quad G_{1}=\Omega\left(1-\pi_{M} s\right) I_{1}(M, S, r)>0 \\
& F_{2}=\frac{\alpha_{M}}{\alpha_{S}} \frac{p_{S}}{p_{M}} G_{2}+I_{2}>0 ; \quad G_{2}=\Omega\left(1-\pi_{M} s\right) I_{2}(M, S, r)>0 \\
& F_{3}=\frac{\alpha_{M}}{\alpha_{S}} \frac{p_{S}}{p_{M}} G_{3}>0 ; \quad G_{3}=\Omega \eta \epsilon>0 \\
& F_{4}=\frac{\alpha_{M}}{\alpha_{S}} \frac{p_{S}}{p_{M}} G_{4}+X^{\prime}>0 ; \quad G_{4}=\Omega\left[\left(1-\pi_{M} s\right) X^{\prime}(\eta)+Z \epsilon\right]>0 \\
& F_{5}=\frac{\alpha_{M}}{\alpha_{S}} \frac{p_{S}}{p_{M}} G_{5}+I_{3}<0 ; \quad G_{5}=\Omega\left(1-\pi_{M} s\right)\left(I_{3}(M, S, r)<0\right. \\
& \Omega=\alpha_{S} \frac{p_{M}}{p_{S}} \frac{1}{\theta+s\left(\alpha_{M} \pi_{M}+\alpha_{S} \pi_{S}\right)}
\end{aligned}
$$

Standard Keynesian adjustment assumptions imply that

$$
\begin{aligned}
\dot{M} & =\lambda_{M}[F(M, S, Z, \eta, r)-M] \\
\dot{S} & =\lambda_{S}[G(M, S, Z, \eta, r)-S]
\end{aligned}
$$

where $\lambda_{M}$ and $\lambda_{S}$ are the adjustment speeds in the two sectors. The Jacobian is given by

$$
J\left(\sigma_{M}, \sigma_{S}\right)=\left(\begin{array}{cc}
\lambda_{M}\left(F_{1}-1\right) & \lambda_{M} F_{2} \\
\lambda_{S} G_{1} & \lambda_{S}\left(G_{2}-1\right)
\end{array}\right)
$$

Stability requires that

$$
\begin{aligned}
\operatorname{Det} J & =\lambda_{M} \lambda_{S}\left[\left(1-F_{1}\right)\left(1-G_{2}\right)-G_{1} F_{2}\right]>0 \\
T R(J) & =\lambda_{M}\left(F_{1}-1\right)+\lambda_{S}\left(G_{2}-1\right)<0
\end{aligned}
$$

The conditions are satisfied for all positive adjustment speeds $\left(\lambda_{M}>0, \lambda_{S}>0\right)$ if

$$
\begin{aligned}
G_{1} F_{2} & <\left(1-F_{1}\right)\left(1-G_{2}\right) \\
F_{1} & <1 \\
G_{2} & <1
\end{aligned}
$$




\section{Appendix B: non-tradable comparative statics - constant interest and exchange rate}

We have

$$
\begin{aligned}
M & =F(M, S, Z, \eta, r) \\
S & =G(M, S, Z, \eta, r)
\end{aligned}
$$

Using the implicit function theorem, it follows that for any exogenous variable $x$,

$$
\begin{aligned}
\left(\begin{array}{c}
\frac{\partial M}{\partial x} \\
\frac{\partial S}{\partial x}
\end{array}\right) & =\left(\begin{array}{cc}
1-F_{1} & -F_{2} \\
-G_{1} & 1-G_{2}
\end{array}\right)^{-1}\left(\begin{array}{c}
\frac{\partial F}{\partial x} \\
\frac{\partial G}{\partial x}
\end{array}\right) \\
& =\frac{1}{\left(1-F_{1}\right)\left(1-G_{2}\right)-G_{1} F_{2}}\left(\begin{array}{cc}
1-G_{2} & F_{2} \\
G_{1} & 1-F_{1}
\end{array}\right)\left(\begin{array}{c}
\frac{\partial F}{\partial x} \\
\frac{\partial G}{\partial x}
\end{array}\right)
\end{aligned}
$$

and - using the results in Appendix A for the signs of partials - we get

$$
\begin{aligned}
\frac{\partial M}{\partial Z}=\frac{F_{3}\left(1-G_{2}\right)+F_{2} G_{3}}{\left(1-F_{1}\right)\left(1-G_{2}\right)-G_{1} F_{2}}>0 ; & \frac{\partial S}{\partial Z}=\frac{G_{1} F_{3}+\left(1-F_{1}\right) G_{3}}{\left(1-F_{1}\right)\left(1-G_{2}\right)-G_{1} F_{2}}>0 \\
\frac{\partial M}{\partial \eta}=\frac{F_{4}\left(1-G_{2}\right)+F_{2} G_{4}}{\left(1-F_{1}\right)\left(1-G_{2}\right)-G_{1} F_{2}}>0 ; & \frac{\partial S}{\partial \eta}=\frac{G_{1} F_{4}+\left(1-F_{1}\right) G_{4}}{\left(1-F_{1}\right)\left(1-G_{2}\right)-G_{1} F_{2}}>0 \\
\frac{\partial M}{\partial r}=\frac{F_{5}\left(1-G_{2}\right)+F_{2} G_{5}}{\left(1-F_{1}\right)\left(1-G_{2}\right)-G_{1} F_{2}}<0 ; & \frac{\partial S}{\partial r}=\frac{G_{1} F_{5}+\left(1-F_{1}\right) G_{5}}{\left(1-F_{1}\right)\left(1-G_{2}\right)-G_{1} F_{2}}<0
\end{aligned}
$$

Turning to net exports, we have

$$
N X=p_{M} X(\eta)-\theta(C+G)+p_{M} \eta Z
$$

With predetermined investment, $I=\bar{I}$, the link between consumption $C+G$ and the level of output in the tradable sector becomes very simple,

$$
M=\frac{\alpha_{M}}{p_{M}}(C+G)+\bar{I}+X
$$

and

$$
\frac{\partial \frac{\alpha_{M}}{p_{M}}(C+G)}{\partial Z}=\frac{\partial M}{\partial Z}
$$

Hence, using the expressions in Appendix A for the partials $F_{1}, F_{2}, F_{3}, G_{1}$ and 
$G_{3}$, we have $F_{1}=F_{2}=G_{1}=G_{2}=0$ and

$$
\begin{aligned}
\frac{\partial N X}{\partial Z} & =\left[-\frac{\theta}{\alpha_{M}} \frac{\partial \frac{\alpha_{M}}{p_{M}}(C+G)}{\partial Z}+\eta\right] p_{M} \\
& =\left[\frac{-\theta}{\alpha_{M}} \frac{\partial M}{\partial Z}+\eta\right] p_{M} \\
& =\left[\frac{-\theta}{\alpha_{M}} \frac{F_{3}\left(1-G_{2}\right)+F_{2} G_{3}}{\left(1-F_{1}\right)\left(1-G_{2}\right)-G_{1} F_{2}}+\eta\right] p_{M} \\
& =\left[\frac{-\theta}{\alpha_{M}} \frac{F_{3}}{1}+\eta\right] p_{M} \\
& =\left[\frac{-\theta \eta \epsilon}{\theta+s\left(\alpha_{M} \pi_{M}+\alpha_{S} \pi_{S}\right)}+\eta\right] p_{M}>0
\end{aligned}
$$

where the inequality follows from $0<\theta<1$ and, by assumption, $\epsilon \leq 1$ (no fiscal deficit). The term $s\left(\alpha_{M} \pi_{M}+\alpha_{S} \pi_{S}\right)$ in the denominator is the derived effect on domestic saving following a unit increase in consumption. These derived domestic saving effects are positive, and an increase in commodity revenues therefore generates an increase in net exports when investment is predetermined.

By continuity, the qualitative results are unchanged when the effects on investment of changes in output are weak. Strong investment effects, however, could reverse the result; this possibility is not excluded by the Keynesian stability conditions. Intuitively, a positive commodity shock has a direct impact on domestic consumption with derived effects on investment, domestic saving and imports. The trade balance may deteriorate if the derived effects on investment exceed the derived effects on saving. This possibility is compatible with the Keynesian stability condition which requires that the derived effects on investment must be less than the sum of the derived effects on domestic saving and imports.

Analogous to the case with shifts in commodity exports, the effects of depreciations are ambiguous without additional restrictions. A depreciation increases total exports $X(\eta)+\eta Z$ but large derived investment effects may cause imports to rise even more.

Using the expression for $(C+G)$ in equation (14), the effects of an increase in the domestic interest rate are unambiguously positive,

$$
\frac{\partial N X}{\partial r}=-\theta \frac{\partial(C+G)}{\partial r}>0
$$




\section{Appendix C: Short-run comparative statics - in- flation targeting}

We have

$$
\begin{aligned}
M & =\frac{\alpha_{M}}{p_{M}}(C+G)+I(M, S, r)+X(\eta) \\
S & =\frac{\alpha_{S}}{p_{S}}(C+G) \\
w_{A} & =\frac{\alpha_{A}}{N-M-S}(C+G)
\end{aligned}
$$

where

$$
C+G=\frac{p_{M}\left[\left(1-\pi_{M} s\right)(I+X)+\eta Z \epsilon\right]}{\theta+s\left(\alpha_{M} \pi_{M}+\alpha_{S} \pi_{S}\right)}
$$

The new equilibrium, following the rise in $Z$, must have an increase in $S$ and $C+G$ (they move together) and a fall in $M$ compared to the equilibrium before the commodity boom. To see this, we show that a constant $S$ would lead to a contradiction and that $S$ must increase.

Assume that $d Z>0, d r>0, d \eta<0, d S=d(C+G)=0$. To keep $w_{A}$ constant, we now must have $d M=0$ in order to keep $N-M-S$ unchanged. The change in $M$, however, is given by $d M=\frac{\alpha_{M}}{p_{M}} d(C+G)+d I+d X=d I+d X$. Since we know that $\eta$ has fallen and $r$ has risen, $d X<0$ and $d I=I_{M} d M+$ $I_{S} d S+I_{r} d r<I_{M} d M$. It now follows that $\left(1-I_{M}\right) d M<0$ and we have reached a contradiction; if $r$ is raised sufficiently to make $S$ unchanged, then the tradable sector must contract and the result would be a decline in informal sector wages. The new equilibrium must involve a smaller rise in $r$ which means that the output of the nontradable formal sector must expand.

Inflation targeting is based on the presumption that an increase in the real interest rate will reduce inflation. In the present context, this means that a rise in $r$ must cause $w_{A}$ to fall and that the rise in $r$ must be smaller than the rise that would give $d S=0$.

The decline in $M$ follows from the observation that an increase in $S$ (and thereby in $C+G$ ) must be matched by a fall in $M+S$ to prevent an increase in the average income in the informal sector.

\section{Appendix D: Endogenous expenditure shares}

Changes in the real exchange rate is the only source of short run movements in relative prices if the prices of domestically produced goods are predetermined. The consumption shares depend on relative prices and we assume that imported consumption goods and domestically produced tradable goods are substitutes while imports and nontradables are complements. Formally,

$$
\frac{\partial \alpha_{M}}{\partial \eta}>0, \quad \frac{\partial \alpha_{S}}{\partial \eta}<0, \quad \frac{\partial \alpha_{A}}{\partial \eta}=\frac{\alpha_{A}}{\alpha_{S}} \frac{\partial \alpha_{S}}{\partial \eta}<0
$$


The last inequality says that exchange rate movements have the same proportional effect on the formal and informal nontradables, leaving the ratio $\alpha_{A} / \alpha_{S}$ unchanged.

Inflation targeting implies that a positive shock to $Z$ is met by a rise in interest rates and a decline in $\eta$ (an appreciation) that keeps average incomes in the informal sector unchanged. Proceeding along the same lines as in Appendix $\mathrm{C}$, we first show that compared with the pre-shock equilibrium, the output of nontradables must increase. Assume that $S$ were unchanged. Using equations (39) and (37)-(38) this implies that $M$ would also have to be unchanged in order for $w_{A}$ to stay constant. But using equation (36) we have $d M<0$, following the same steps as in Appendix B.

Still following the steps in Appendix B, we can conclude that $S$ and thereby $w_{A} L_{A}=w_{A}(N-M-S)$ must increase. To keep $w_{A}$ unchanged it follows that $L_{A}$ must increase which - with an increase in $S$ - requires a decline in $M$. Thus, the results are robust to endogenous expenditures shares.

A simple example in which inflation targeting leads to an increase in $M$ and a decline in $S$ can be constructed with $I=\bar{I}, X=\bar{X}, s=0, \theta$ and $\alpha_{A}$ constant, $\alpha_{M}^{\prime}(\eta)=-\alpha_{S}^{\prime}(\eta)<0$ (since $\alpha_{S}+\alpha_{M}=1-\theta-\alpha_{A}$ is constant) and $p_{M}>p_{S}$. With these assumptions, we have (using (36)-(37)

$$
\begin{aligned}
-(d M+d S) & =\left(\frac{\alpha_{M}}{p_{M}}+\frac{\alpha_{S}}{p_{S}}\right) d(C+G)+\frac{1}{p_{M}}(C+G) d \alpha_{M}+\frac{1}{p_{S}}(C+G) d \alpha_{S} \\
& =\left(\frac{\alpha_{M}}{p_{M}}+\frac{\alpha_{S}}{p_{S}}\right) d(C+G)+(C+G)\left(\frac{1}{p_{M}}-\frac{1}{p_{S}}\right) d \alpha_{M}
\end{aligned}
$$

Using 38 , the inflation constraint - keeping $w_{A}$ unchanged - implies that

$$
d M+d S=\frac{\alpha_{A}}{w_{A}} d(C+G)
$$

Combining these equations (40)-(41), we have

$$
-(C+G)\left(\frac{1}{p_{M}}-\frac{1}{p_{S}}\right) d \alpha_{M}=\left(\frac{\alpha_{M}}{p_{M}}+\frac{\alpha_{S}}{p_{S}}+\frac{\alpha_{A}}{w_{A}}\right) d(C+G)
$$

A positive shock to $Z$ is met by a rise in interest rates, the exchange rate appreciates and $\alpha_{M}$ increases. Equation (42) implies that this must be accompanied by a rise in $(C+G)$. If both $\alpha_{M}$ and $(C+G)$ increase, then $M$ must also increase (see equation (36)) while $M+S$ must fall (see equation (41)). Hence, $S$ must fall.

Intuitively, as the exchange rate appreciates, consumption shifts towards $M$ goods (because $\alpha_{M}^{\prime}=-\alpha_{S}^{\prime}<0$ ). This shift reduces total labor demand in the formal sectors (because $p_{M}>p_{S}$ and $q_{M}=q_{S}$ ), and an increase in total consumption is needed to keep informal sector incomes constant. But the increase in consumption cannot fully offset the effect of the fall in $\alpha_{S}$ on the demand for $S$ goods; if it did, we would have had a rise in formal sector employment, and the average income in the informal sector would have increased. 


\section{Appendix E: Imports of intermediate goods}

If both the markup and labor productivity are constant (with labor productivity still normalized at 1) we have

$$
\begin{aligned}
p_{M} & =\left(1+m_{M}\right)\left(w_{M}+\gamma_{M} p_{M} \eta\right)=p_{M}(\eta) ; \quad p_{M}^{\prime} \geq 0 \\
p_{S} & =\left(1-m_{S}\right)\left(w_{S}+\gamma_{S} p_{M} \eta\right)=p_{S}(\eta) ; \quad p_{S}^{\prime} \geq 0 \\
\pi_{M} & =\frac{m_{M}}{1+m_{M}} \frac{1}{1-\gamma_{M} \eta} ; \quad \pi_{M}^{\prime} \geq 0 \\
\pi_{S} & =\frac{m_{S}}{1+m_{S}} \frac{1}{1-\gamma_{S} \eta \frac{p_{M}}{p_{S}}} ; \quad \pi_{S}^{\prime} \geq 0
\end{aligned}
$$

The equilibrium conditions in equations (11)-(13) still hold, but the expression for $(C+G)$ in equation (14) becomes modified. It now reads

$$
C+G=\frac{p_{M}\left[\left(1-\pi_{M} s\right)\left(1-\gamma_{M} \eta\right)(I+X)+\eta Z \epsilon\right]}{\theta+\alpha_{M}\left[s \pi_{M}+\gamma_{M} \eta\left(1-s \pi_{M}\right)\right]+\alpha_{S}\left[s \pi_{S}+\gamma_{S} \frac{p_{M}}{p_{S}} \eta\left(1-s \pi_{S}\right)\right]}
$$

The wage in the tradable sector is predetermined, and an unchanged wage ratio requires that $w_{A}$ not change. We have

$$
w_{A}=\frac{1}{N-M-S} \alpha_{A}(C+G)
$$

and an unchanged $w_{A}$ implies that

$$
-d(M+S)=\alpha_{A} d(C+G)
$$

Using (11)-(12) we have

$$
\begin{aligned}
d\left(p_{S} S\right) & =\alpha_{S} d(C+G) \\
d\left(p_{M} M\right) & =\frac{\alpha_{M}}{\alpha_{S}} d\left(p_{S} S\right)+d\left(p_{M} I\right)+d\left(p_{M} X\right)
\end{aligned}
$$

Case 1: Constant prices If the prices are constant, an increase in interest rates and the associated appreciation of the exchange rate will reduce the cost of intermediate inputs and raise the profit shares. The increase in profit share, in turn, will have a negative impact on aggregate consumption $(C+G)$; equation (43) implies that $\partial(C+G) / \partial \pi_{i}<0$.

Monetary policy now has a more powerful effect on aggregate demand, but a commodity boom still raises $S$ and reduces $M$. The proof can proceed as in in Appendix C. If the change in $S$ were negative then, using (46), $M$ would also fall, and (44) cannot hold. Thus, $S$ and thereby $C+G$ must increase. Equation (44) now implies that this increase must be combined with a reduction in $M$. 
Case 2: Constant markups If markups are kept constant, both prices and profit shares become increasing functions of the real exchange rate. Depending on how relative prices respond to exchange rate shocks, this opens the possibility for results other than a fall in $M$ and an increase in $S$.

If $d \frac{p_{S}}{p_{M}} / d \eta \geq 0$, we must have an increase in $S$, but $M$ need not fall. The proof of a rise in $S$ again follows the same recipe. If $d S \leq 0$, we must have $d\left(p_{S} S\right)<0, d(C+G)<0$ and $d\left(\frac{p_{S}}{p_{M}} S\right)<0$. Hence,

$$
d M=\frac{\alpha_{M}}{\alpha_{S}} d\left(\frac{p_{S}}{p_{M}} S\right)+d I+d X<0
$$

It follows that equation (44) cannot be satisfied if $d S \leq 0$.

To see that $M$ need not fall, note that with exogenous values of both investment and exports $(d I=d X=0)$ and $d \frac{p_{S}}{p_{M}} / d \eta=0$, equation (46) reduces to

$$
d M=\frac{\alpha_{M}}{\alpha_{S}} d S
$$

Thus, $M$ and $S$ must move in the same direction, and since prices fall, they must both increase in order to satisfy equation (44). Intuitively, the average informal sector income $w_{A}$ is determined by the number of workers and the nominal demand. Thus, if nominal demand fall, a reduction in the number of workers in the informal sector is needed in order to keep the average income unchanged.

If $d \frac{p_{S}}{p_{M}} / d \eta<0$, the results can be different. Again, consider the simple case with $d I=d X=0$. Now, if $d \frac{p_{S}}{p_{M}} / d \eta<0$, we have

$$
d M=\frac{\alpha_{M}}{\alpha_{S}} d\left(\frac{p_{S}}{p_{M}} S\right)=\frac{\alpha_{M}}{\alpha_{S}} S d\left(\frac{p_{S}}{p_{M}}\right)+\frac{\alpha_{M}}{\alpha_{S}} \frac{p_{S}}{p_{M}} d S>\frac{\alpha_{M}}{\alpha_{S}} \frac{p_{S}}{p_{M}} d S
$$

Using (44), the changes in $M$ and $S$ cannot both be negative. Thus, we must have $d M>0$; depending on the parameters and the magnitude of the decline in $p_{S}$, the change in the output of nontradables can go either way.

\section{Appendix F: Imported and nontradable invest- ment goods}

Imported investment goods Assume the extreme case in which all $I$ is imported. In this case:

$$
\begin{gathered}
p_{M} M=\alpha_{M}(C+G)+p_{M} X \\
N X=p_{M} X(\eta)-\theta(C+G)-\eta p_{M} I+p_{M} \eta Z
\end{gathered}
$$

The equilibrium conditions for the $A$ and $S$ sectors (equations (12)-(13)) are unchanged. For the $M$-sector, however, equilibrium now requires that

$$
M=\frac{\alpha_{M}\left[\left(1-\pi_{M} s\right) X+\epsilon \eta Z\right]}{\theta+s\left(\alpha_{S} \pi_{S}+\alpha_{M} \pi_{M}\right)}+X
$$


Proceeding analogously to appendix B, the short run effects (without inflation targeting) are qualitatively the same as before. They will also be quantitatively the same in the particular case that both profit share and the capital accumulation are predetermined; in other cases, they will be weaker.

Considering the impact of the inflation targeting policy, we now have

$$
C+G=\frac{p_{M}\left[\left(1-\pi_{M} s\right) X+\epsilon \eta Z\right]}{\theta+s\left(\alpha_{S} \pi_{S}+\alpha_{M} \pi_{M}\right)}
$$

The demand for investment goods no longer generates domestic income, but $C+G$ still depends positively on $M, S, Z$ and $\eta$ (and thereby negatively on $r$ ). Thus, the analysis can proceed as in Appendix C, and the qualitative results are unchanged.

Nontradable investment goods If investment goods are domestically produced but nontradable, we have

$$
\begin{gathered}
p_{M} M=\alpha_{M}(C+G)+p_{M} X \\
p_{S} S=\alpha_{S}(C+G)+p_{S} I
\end{gathered}
$$

Aggregate consumption and the no-inflation condition can be written

$$
\begin{aligned}
C+G & =\frac{\left.\left(1-\pi_{S} s\right) p_{S} I+\left(1-\pi_{M} s\right) p_{M} X+\epsilon \eta Z\right\}}{\theta+\alpha_{S} \pi_{S} s+\alpha_{M} p i_{M} s} \\
\frac{w_{M}}{\mu} & =w_{A}=\frac{\alpha_{A}}{N-M-S} \frac{\left(1-\pi_{S} s\right) p_{S} I+p_{M}\left[\left(1-\pi_{M} s\right) X+\epsilon \eta Z\right]}{\theta+\alpha_{S} \pi_{S} s+\alpha_{M} p i_{M} s}
\end{aligned}
$$

The relative impact of a commodity boom on $S$ and $M$ under inflation targeting now becomes ambiguous. If $I$ is insensitive to changes in $r$ while $X$ is sensitive to changes in $\eta$, the qualitative results will be as in Appendix C. If these assumptions are reversed and $I$ is sensitive to changes in $r$ while $X$ is insensitive to changes in $\eta$, the results in Appendix $\mathrm{C}$ may also be reversed: inflation targeting may produce an equilibrium with a higher $M$ and a lower $S$.

We show these results by considering the two extreme cases, one with $I$ independent of $r$ and one with $X$ exogenous (independent of $\eta$ ).

If $I$ is independent of $r$, changes in the interest rate have no direct effect on the demand for domestically produced goods, and inflation targeting works entirely through the effects of the interest rate in the real exchange rate; the analysis of this case is completely analogous to the case with imported investment goods.

If $X$ is independent of $\eta$, we can follow the steps in Appendix C. Assume that $d Z>0, d r>0, d \eta<0, d X=0, d M=d(C+G)=0$. To keep $w_{A}$ constant, we now would need to have $d S=0$ in order to keep $N-M-S$ unchanged. The change in $S$, however, is given by $d S=\frac{\alpha_{S}}{p_{S}} d(C+G)+d I=d I$. Since we know that $r$ has risen, $d I=I_{M} d M+I_{S} d S+\stackrel{p}{I}_{r} d r<I_{S} d S$. It now follows that $\left(1-I_{S}\right) d S<0$ and we have reached a contradiction; if $r$ is raised sufficiently to make $M$ unchanged, then the nontradable sector must contract, and the result 
would be a decline in informal sector wages. Thus, the new equilibrium must involve a smaller rise in $r$ which means that the output of the tradable formal sector must expand. The decline in $S$ follows from the observation that an increase in $M$ (and thereby in $C+G$ ) must be matched by a fall in $M+S$ to prevent an increase in the average income in the informal sector. 


\section{References}

Akerlof, George A, William T Dickens, et al. (1996). "The macroeconomics of low inflation". In: Brookings papers on economic activity 1996.1, pp. 1-76.

Akerlof, George A and Janet L Yellen (1990). "The fair wage-effort hypothesis and unemployment". In: The Quarterly Journal of Economics 105.2, pp. $255-283$.

Antunes, Ricardo and Ruy Braga (2014). "Os dias que abalaram o Brasil: as rebeliões de junho, julho de 2013". In: Revista de Políticas Públicas 18, pp. 4147.

Araujo, Ricardo Azevedo and Gilberto Tadeu Lima (2007). "A structural economic dynamics approach to balance-of-payments-constrained growth". In: Cambridge Journal of Economics 31.5, pp. 755-774.

Barbosa-Filho, Nelson H (2011). "Exchange rates, growth and inflation: what if the income elasticities of trade flows respond to relative prices?" In: Capital Without Borders: Challenges to Development 1, p. 53.

- (2014). "A structuralist inflation curve". In: metroeconomica 65.2, pp. 349376.

- (2015). "Monetary policy with a volatile exchange rate: the case of Brazil since 1999". In: Comparative Economic Studies 57.3, pp. 401-425.

Barro, Robert J (1995). "Inflation and Economic Growth". In: NBER Working Paper w5326.

Barros, Octavio de and Fabio Giambiagi (2008). Brasil globalizado: o Brasil em um mundo surpreendente. Elsevier Brasil.

Baumol, William J and William G Bowen (1965). "On the performing arts: the anatomy of their economic problems". In: The American economic review $55.1 / 2$, pp. $495-502$.

Bewley, Truman F (1998). "Why not cut pay?" In: European Economic Review 42.3-5, pp. 459-490.

Bielschowsky, Ricardo, Gabriel Coelho Squeff, and Lucas Ferraz Vasconcelos (2015). Evolução dos investimentos nas três frentes de expansão da economia brasileira na década de 2000. Tech. rep. Instituto de Pesquisa Econômica Aplicada (IPEA).

Bowles, Samuel (1985). "The production process in a competitive economy: Walrasian, neo-Hobbesian, and Marxian models". In: The American economic review 75.1 , pp. $16-36$.

Braga, Julia Medeiros (Dec. 2013). "A Inflação Brasileira na Década de 2000 e a Importância de Políticas Não Monetárias de Controle". In: Economia e Sociedade 22, pp. 697-727.

Brenck, Clara and Laura Carvalho (2019). "The equalizing spiral in early 21st century Brazil: a Kaleckian model with sectoral heterogeneity". In: University of Sao Paulo (FEA-USP) - Economics Department Working Paper Series.

Bresser-Pereira, Luiz Carlos, Jose Luis Oreiro, and Nelson Marconi (2014). Developmental Macroeconomics: new developmentalism as a growth strategy. Routledge. 
Bresser-Pereira, Luiz Carlos and Fernando Rugitsky (2018). "Industrial policy and exchange rate scepticism". In: Cambridge Journal of Economics 42.3, pp. 617-632.

Brito, Ricardo D and Brianne Bystedt (2010). "Inflation targeting in emerging economies: Panel evidence". In: Journal of Development Economics 91.2, pp. 198-210.

Bruno, Michael and William Easterly (1998). "Inflation Crises and Long-Run Growth". In: Journal of Monetary Economics 41.1, pp. 3-26.

Carvalho, Laura and Fernando Rugitsky (2015). Growth and distribution in Brazil the 21st century: revisiting the wage-led versus profit-led debate. University of Sao Paulo (FEA-USP) - Economics Department Working Paper Series.

Clark, Colin (1940). The conditions of economic progress. London : Macmillan.

Couto, Claudio (2014). Desordem e progresso. URL: http://www.valor.com. br/politica/3433450/desordem-e-progresso.

Currie, Janet and Firouz Gahvari (2008). "Transfers in cash and in-kind: Theory meets the data". In: Journal of Economic Literature 46.2, pp. 333-83.

De Castro, Marcos R et al. (2015). "SAMBA: Stochastic analytical model with a bayesian approach". In: Brazilian Review of Econometrics 35.2, pp. 103170.

DIEESE (2005). Estudos e Pesquisas - O movimento grevista em 2004.

- (2014). Estudos e Pesquisas - Balanço das greves em 2013.

Dosi, Giovanni and Richard R Nelson (2010). "Technical change and industrial dynamics as evolutionary processes". In: Handbook of the Economics of Innovation. Vol. 1. Elsevier, pp. 51-127.

Dweck, Esther, Miriam Chaves, and Emilio Chernavsky (2013). "O Modelo de desenvolvimento Brasileiro: análise de seus fundamentos e o papel das macropoliticas federais". In: Congresso Internacional Del Clad sobre la Reforma Del Estado y la Administracion Publica. Vol. 18.

Fraga, Arminio, Ilan Goldfajn, and Andre Minella (2003). "Inflation targeting in emerging market economies". In: NBER macroeconomics annual 18, pp. 365-400.

Gala, Paulo (2007). "Real exchange rate levels and economic development: theoretical analysis and econometric evidence". In: Cambridge Journal of economics 32.2 , pp. $273-288$.

Garber, Gabriel et al. (2019). "Household debt and recession in Brazil". In: Handbook of US Consumer Economics. Elsevier, pp. 97-119.

Gomes, Fábio Augusto Reis and Lourenço Senne Paz (2005). "Can real exchange rate devaluation improve the trade balance? The 1990-1998 Brazilian case". In: Applied Economics Letters 12.9, pp. 525-528.

Goodfriend, Marvin and Robert G King (1997). "The new neoclassical synthesis and the role of monetary policy". In: NBER macroeconomics annual 12, pp. 231-283.

Guzman, Martin, Jose Antonio Ocampo, and Joseph E Stiglitz (2018). "Real exchange rate policies for economic development". In: World Development 110, pp. 51-62. 
Haddad, Fernando (2012). Interview with Fernando Haddad for Folha de São Paulo. URL: https : / / www1 folha . uol . com . br / saopaulo/2012 / 04 / 1072605 - qualidade-de-vida-so-aumentou-da-porta-para-dentrodiz-fernando-haddad.shtml.

Haraguchi, Nobuya, Charles Fang Chin Cheng, and Eveline Smeets (2017). "The importance of manufacturing in economic development: Has this changed?" In: World Development 93, pp. 293-315.

Hicks, J. R. (1975). Crisis in Keynesian economics. Blackwell, Oxford.

IMF (2018). Regional Economic Outlook, Western Hemisphere Department: Seizing the Momentum. International Monetary Fund.

Kahneman, Daniel, Jack Knetsch, and Richard Thaler (1986). "Fairness as a constraint on profit seeking: Entitlements in the market". In: The American economic review, pp. $728-741$.

Keynes, John Maynard (1936). The general theory of interest, employment and money. London: MacMillan.

Komatsu, Bruno Kawaoka and Naercio Aquino Menezes Filho (2015). "Salário minimo e desigualdade salarial: um estudo com densidades contrafactuais nas regiões metropolitanas brasileiras". In: Pesquisa e Planejamento Econômico.

Krugman, Paul (1987). "The narrow moving band, the Dutch disease, and the competitive consequences of Mrs. Thatcher: Notes on trade in the presence of dynamic scale economies". In: Journal of development Economics 27.1-2, pp. $41-55$.

La Porta, Rafael and Andrei Shleifer (2014). "Informality and development". In: Journal of Economic Perspectives 28.3, pp. 109-26.

Lavinas, Lena (2013). "21st century welfare". In: New Left Review 84.6, pp. 540.

- (2017). Takeover of social policy by financialization. Springer.

Leibenstein, Harvey (1957). "The theory of underemployment in backward economies". In: Journal of Political Economy 65.2, pp. 91-103.

Lewis, W Arthur (1954). "Economic development with unlimited supplies of labour". In: The manchester school 22.2, pp. 139-191.

Libman, Emiliano, Juan Antonio Montecino, and Arslan Razmi (2019). "Sustained investment surges". In: Oxford Economic Papers 71.4, pp. 1071-1095.

Lima, Gilberto Tadeu and Mark Setterfield (2008). "Inflation targeting and macroeconomic stability in a Post Keynesian economy". In: Journal of Post Keynesian Economics 30.3, pp. 435-461.

Loureiro, Pedro Mendes (2020). "Class inequality and capital accumulation in Brazil, 1992-2013". In: Cambridge Journal of Economics 44.1, pp. 181-206.

Maka, Alexis, Fernando Barbosa, et al. (2013). "Phillips curves: An encompassing test". In: XLI Encontro Nacional de Economia (ANPEC).

Maka, Alexis and Fernando Barbosa (2017). "The trade-off between inflation and economic activity in Brazil". In: Instituto de Pesquisa Econômica Aplicada (Ipea) - Discussion Paper.

Marconi, Nelson, Igor L Rocha, and Guilherme R Magacho (2016). "Sectoral capabilities and productive structure: An input-output analysis of the key 
sectors of the Brazilian economy". In: Brazilian Journal of Political Economy 36.3, pp. 470-492.

Martins, Guilherme Klein (2017). "Lucratividade, desenvolvimento técnico e distribuição funcional: uma análise da economia brasileira entre 2000 e 2013". Master thesis. Universidade de São Paulo.

Martins, Guilherme Klein and Fernando Rugitsky (2018). "The commodities boom and the profit squeeze: output and profit cycles in Brazil (1996-2016)". In: University of Sao Paulo (FEA-USP) - Economics Department Working Paper Series.

Mesquita, Mário et al. (2014). "A política econômica do governo Dilma: a volta do experimentalismo". In: Sob a luz do sol: uma agenda para o Brasil $C D P P$.

Miguez, T (2016). "Evolução da formação bruta de capital fixo na economia brasileira 2000-2013: Uma análise multissetorial a partir das Matrizes de Absorção de Investimento (MAIs)". PhD thesis. PhD dissertation, IE/UFRJ, Rio de Janeiro.

Moura, Guilherme and Sergio Da Silva (2005). "Is there a Brazilian J-curve?" In: Economics Bulletin 6.10, pp. 1-17.

Nassif, André, Carmem Feijó, and Eliane Araújo (2020). "Macroeconomic policies in Brazil before and after the 2008 global financial crisis: Brazilian policymakers still trapped in the New Macroeconomic Consensus guidelines". In: Cambridge Journal of Economics 44.4, pp. 749-779.

Neri, Marcelo, Gustavo Gonzaga, and José Márcio Camargo (2001). "Salário Mınimo". In: Brazilian Journal of Political Economy 21.2.

OECD (2005). OECD Economic Surveys: Brazil.

- (2018). OECD Economic Surveys: Brazil.

Orair, Rodrigo Octavio and Sergio Wulff Gobetti (2017). "Brazilian fiscal policy in perspective: from expansion to austerity". In: The Brazilian economy since the great financial crisis of 2007/2008. Springer, pp. 219-244.

Oreiro, José Luis and Luciano D'Agostini (2017). "Macroeconomic policy regimes, real exchange rate overvaluation, and performance of the Brazilian economy (2003-2015)". In: Journal of Post Keynesian Economics 40.1, pp. 27-42.

Pereira, Rafael HM et al. (2020). "Desigualdades socioespaciais de acesso a oportunidades nas cidades brasileiras". In: Instituto de Pesquisa Econômica Aplicada (Ipea) - Discussion Paper.

Pessôa, Samuel (2017). "Escolha de caminhos pela esquerda no Brasil é de causar perplexidade". In: Revista Conjuntura Econômica 71.4, pp. 10-11.

- (2018). "Será que o Brasil está finalmente vacinado contra o populismo econômico?" In: Revista Conjuntura Econômica 72.4, pp. 12-13.

Pollin, Robert and Andong Zhu (2006). "Inflation and economic growth: A crosscountry nonlinear analysis". In: Journal of post Keynesian economics 28.4, pp. 593-614.

Porcile, Gabriel and Gilberto Tadeu Lima (2010). "Real exchange rate and elasticity of labour supply in a balance-of-payments-constrained macrodynamics". In: Cambridge Journal of Economics 34.6, pp. 1019-1039. 
Razmi, Arslan, Martin Rapetti, and Peter Skott (2012). "The real exchange rate and economic development". In: Structural Change and Economic Dynamics 23.2, pp. 151-169.

Rodrik, Dani (2008). "The real exchange rate and economic growth". In: Brookings papers on economic activity 2008.2, pp. 365-412.

- (2013). "Unconditional convergence in manufacturing". In: The Quarterly Journal of Economics 128.1, pp. 165-204.

- (2016). "Premature deindustrialization". In: Journal of economic growth 21.1, pp. 1-33.

Ros, Jaime (2013). Rethinking economic development, growth, and institutions. Oxford University Press.

Ros, Jaime and Peter Skott (1998). "Dynamic effects of trade liberalization and currency overvaluation under conditions of increasing returns". In: The Manchester School 66.4, pp. 466-489.

Rossi, Pedro, Guilherme Mello, and Pedro Paulo Zahluth Bastos (2020). "The growth model of the PT governments: a furtadian view of the limits of recent brazilian development". In: Latin American Perspectives 47.1, pp. 100-114.

Rowthorn, Robert E (1977). "Conflict, inflation and money". In: Cambridge Journal of Economics 1.3, pp. 215-239.

Rugitsky, Fernando (2017). "The rise and fall of the Brazilian economy (20042015): the economic antimiracle". In: 45th Brazilian National Meeting of Economics (ANPEC).

Ryoo, Soon and Peter Skott (2013). "Public debt and full employment in a stock-flow consistent model of a corporate economy". In: Journal of Post Keynesian Economics 35.4, pp. 511-528.

Saad Filho, Alfredo (2016). "Social policy beyond neoliberalism: from conditional cash transfers to pro-poor growth". In: Journal of Poverty Alleviation and International Development 7.1, pp. 67-94.

Saboia, Joao and Joao Hallak Neto (2018). "Salario minimo e distribuicao de renda no Brasil a partir dos anos 2000". In: Economia e Sociedade 27.1, pp. $265-285$.

Sachsida, Adolfo (2013). "Inflação, desemprego e choques cambiais: uma revisão da literatura sobre a curva de Phillips no Brasil". In: Revista Brasileira de Economia 67.4, pp. 549-559.

Santos, Claudio Hamilton Matos dos et al. (2018). "A natureza da inflação de serviços no Brasil: 1999-2014". In: Economia e Sociedade 27.1, pp. 199-231.

Sarel, Michael (1996). "Nonlinear effects of inflation on economic growth". In: Internation Monetary Fund - Staff Papers 43.1, pp. 199-215.

Savastano, Miguel A, Paul R Masson, and Sunil Sharma (1997). The scope for inflation targeting in developing countries. 97-130. International Monetary Fund.

Serrano, Franklin (2010). "Juros, câmbio e o sistema de metas de inflação no Brasil". In: Brazilian Journal of Political Economy 30.1, pp. 63-72.

Serrano, Franklin and Ricardo Summa (2015). "Aggregate demand and the slowdown of Brazilian economic growth in 2011-2014". In: Nova Economia 25.SPE, pp. 803-833. 
Shafir, Eldar, Peter Diamond, and Amos Tversky (1997). "Money illusion". In: The Quarterly Journal of Economics 112.2, pp. 341-374.

Shapiro, Carl and Joseph E Stiglitz (1984). "Equilibrium unemployment as a worker discipline device". In: The American Economic Review 74.3, pp. 433444.

Sims, Christopher A (2003). "Implications of rational inattention". In: Journal of monetary Economics 50.3, pp. 665-690.

Singer, Andre (2020). "The Failure of Dilma Rousseff's Developmentalist Experiment: A Class Analysis". In: Latin American Perspectives 47.1, pp. 152168.

Skott, Peter (2005). "Fairness as a source of hysteresis in employment and relative wages". In: Journal of Economic Behavior \& Organization 57.3, pp. 305331.

- (2020). "Fiscal policy and structural transformation in developing economies". In: UMass Amherst Economics Working Papers.

Souza, Pedro HGF and Marcelo Medeiros (2015). "Top income shares and inequality in Brazil, 1928-2012". In: Sociologies in Dialogue 1.1.

Summa, Ricardo (2011). "Uma avaliação critica das estimativas da curva de Phillips no Brasil". In: Pesquisa $\& 3$ Debate. Revista do Programa de Estudos Pós-Graduados em Economia Política. 22.2 (40).

- (2016). "Uma nota sobre a relação entre salário mínimo e inflação no Brasil a partir de um modelo de inflação de custo e conflito distributivo". In: Economia e Sociedade 25.3, pp. 733-756.

Summa, Ricardo and Franklin Serrano (2018). "Distribution and conflict inflation in Brazil under inflation targeting, 1999-2014". In: Review of Radical Political Economics 50.2, pp. 349-369.

Summers, Lawrence H (2015). "Demand side secular stagnation". In: American Economic Review 105.5, pp. 60-65.

UNCTAD (2017). Commodity Dependence, Growth and Human Development. United Nations.

- (2019). Commodity Dependence: A Twenty-Year Perspective. United Nations.

Williamson, John (1990). "Latin American Adjustment: How much has Happened?" In: Washington, DC: Institute for International Economics.

- (2004). "A Short History of the Washington Consensus". In: From the Washington Consensus towards a new Global Governance.

World Bank (2017). A fair adjustment: efficiency and equity of public spending in Brazil. 